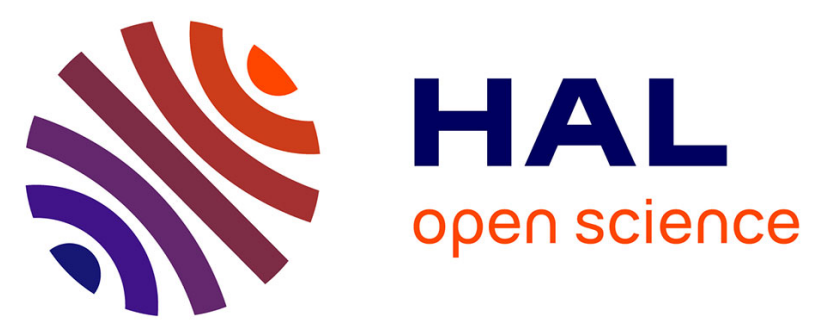

\title{
Biogeochemical modelling of anaerobic vs. aerobic methane oxidation in a meromictic crater lake (Lake Pavin, France)
}

F. Lopes, Eric Viollier, A. Thiam, Gil Michard, G. Abril, A. Groleau, F. Prévot, Jean-François Carrias, Patrick Albéric, Didier Jézéquel

\section{To cite this version:}

F. Lopes, Eric Viollier, A. Thiam, Gil Michard, G. Abril, et al.. Biogeochemical modelling of anaerobic vs. aerobic methane oxidation in a meromictic crater lake (Lake Pavin, France). Applied Geochemistry, 2011, 26, pp.1919-1932. 10.1016/j.apgeochem.2011.06.021 . insu-00651276

\section{HAL Id: insu-00651276 \\ https://hal-insu.archives-ouvertes.fr/insu-00651276}

Submitted on 22 Dec 2011

HAL is a multi-disciplinary open access archive for the deposit and dissemination of scientific research documents, whether they are published or not. The documents may come from teaching and research institutions in France or abroad, or from public or private research centers.
L'archive ouverte pluridisciplinaire HAL, est destinée au dépôt et à la diffusion de documents scientifiques de niveau recherche, publiés ou non, émanant des établissements d'enseignement et de recherche français ou étrangers, des laboratoires publics ou privés. 


\title{
Biogeochemical modelling of anaerobic $v s$. aerobic methane oxidation in a meromictic crater lake (Lake Pavin, France)
}

\author{
F. Lopes ${ }^{\mathrm{a}}$, , E. Viollier ${ }^{\mathrm{a}}$, A. Thiamª ${ }^{\mathrm{a}}$, G. Michard ${ }^{\mathrm{a}}$, G. Abril ${ }^{\mathrm{b}}$, A. Groleau ${ }^{\mathrm{a}}$, F. Prévot ${ }^{\mathrm{a}}$, J.- \\ F. Carrias ${ }^{\underline{c}}$, P. Albéric ${ }^{\underline{d}}$, D. Jézéquel ${ }^{\mathrm{a}}$
}

a Laboratoire de Géochimie des Eaux, IPGP \& Université Paris Diderot-Paris 7, Case courrier 7052, 75205 Paris Cedex 13, France

b Laboratoire EPOC, Université Bordeaux 1, UMR CNRS 5805, Avenue des Facultés, 33405 Talence Cedex, France

c Laboratoire «Microorganismes: Génome et Environnement», UMR CNRS 6023, Université Blaise Pascal, 24 Avenue des Landais, 63177 Aubière, France

d Institut des Sciences de la Terre d'Orléans, Université d'Orléans, INSU-CNRS, Campus

Géosciences, 1A rue de la Férolerie, 45071 Orléans Cedex 2, France

\begin{abstract}
Methane is a powerful greenhouse gas and its concentration in the atmosphere has increased over the past decades. Methane produced by methanogenic Archae can be consumed through aerobic and anaerobic oxidation pathways. In anoxic conditions found in freshwater environments such as meromictic lakes, $\mathrm{CH}_{4}$ oxidation pathways involving different terminal electron acceptors such as $\mathrm{NO}_{3}^{-}, \mathrm{SO}_{4}^{2-}$, and oxides of $\mathrm{Fe}$ and $\mathrm{Mn}$ are thermodynamically possible. In this study, a reactive transport model was developed to assess the relative significance of the different pathways of $\mathrm{CH}_{4}$ consumption in the water column of Lake Pavin. In most cases, the model reproduced experimental data collected from the field from June 2006 to June 2007. Although the model and the field measurements suggest that anaerobic $\mathrm{CH}_{4}$ oxidation may contribute to $\mathrm{CH}_{4}$ consumption in the water column of Lake Pavin, aerobic oxidation remains the major sink of $\mathrm{CH}_{4}$ in this lake.
\end{abstract}

\section{Introduction}

Methane can be considered both as an energy resource and as an atmospheric contaminant contributing to the greenhouse effect. Almost 2/3 of the current $\mathrm{CH}_{4}$ emissions are anthropogenic and the present $\mathrm{CH}_{4}$ concentration of 1.77 ppmv is more than twice its preindustrial value. This global increase has contributed to an increase in radiative forcing (Solomon et al., 2007). Emission from wetlands is an important source of $\mathrm{CH}_{4}$, dominating natural sources of $\mathrm{CH}_{4}$ in the atmosphere. In the past decade the overall annual rate of $\mathrm{CH}_{4}$ growth has been reduced to nearly zero and has become highly variable. The decrease is attributed to a temporary reduction in anthropogenic emissions, while the increased variability is attributed to wetland emission (van Huissteden et al., 2008). For northern wetlands, it has been shown that at relatively high water tables, the $\mathrm{CH}_{4}$ flux can change from net emission to net uptake (van Huissteden et al., 2005). Owing to the importance of this reversibility at the global scale, permanent or transient (seasonal) biogeochemical sink pathways need to be characterized.

In wetlands (watercourses, swamps, ponds and lakes) with anoxic, highly reductive conditions, the final stage of natural organic matter decomposition is $\mathrm{CH}_{4}$ production 
(methanogenesis). Methanogens are strictly anaerobic microorganisms of the Archaea type utilizing very simple $\mathrm{C}$ compounds like acetic acid, $\mathrm{CO}_{2}$ and methanol for their energy production (Conrad et al., 1999). The rate of $\mathrm{CH}_{4}$ production by Archae is however limited when alternative electron acceptors (e.g., $\mathrm{NO}_{3}^{-}, \mathrm{SO}_{4}^{2-}, \mathrm{Fe}(\mathrm{III})$ and $\left.\mathrm{Mn}(\mathrm{IV})\right)$ are available (Lovley and Phillips, 1987). Nevertheless, according to Crowe et al. (2010, and associated references), methanogenesis may account for a large part of organic matter recycling even in the presence of significant $\mathrm{Fe}$ (III) particle content, due to surface deactivation by $\mathrm{Fe}$ (hydro)oxides.

The $\mathrm{CH}_{4}$ produced is partly consumed by methanotrophs, $\mathrm{CH}_{4}$-oxidising bacteria (Whiticar, 1993). Methane oxidation can occur aerobically or anaerobically in a wide variety of subsurface and surface environments. Anaerobic oxidation of methane (AOM) is a wellknown mechanism in marine sediments (Elvert et al., 2000). For instance $\mathrm{SO}_{4}$-dependent methane oxidation (SDMO) (using $\mathrm{SO}_{4}^{2-}$ as electron acceptor) has been reported in marine systems.

However, only a few lakes show the occurrence of anaerobic $\mathrm{CH}_{4}$ oxidation ( [Joye et al., 1999], [Eller et al., 2005] and [Ertefai et al., 2008] ). Recently, $\mathrm{NO}_{2}^{-}$and $\mathrm{NO}_{3}^{-}$have been found as suitable substrates for AOM in a freshwater canal sediment (Raghoebarsing et al., 2006). Moreover, Fe and $\mathrm{Mn}$ dependent anaerobic $\mathrm{CH}_{4}$ oxidation (Fe/Mn-AOM) are presented as possible pathways of $\mathrm{CH}_{4}$ consumption (Valentine, 2002). Recently, Crowe et al. (2010) suggested that anaerobic $\mathrm{CH}_{4}$ oxidation coupled to $\mathrm{Fe}$ or Mn reduction may occur in Lake Matano. Extreme conditions, such as high alkalinity or hypersalinity characterize most continental settings exhibiting anaerobic $\mathrm{CH}_{4}$ oxidation, e.g., Big Soda Lake (Iversen et al., 1987), hypersaline Solar Lake (Cytryn et al., 2000) or continental mud volcanoes (Alain et al., 2006).

Meromictic lakes are usually small and widespread (Pourriot and Meybeck, 1995). They represent excellent field laboratories to follow biogeochemical reactions in permanently stratified ecosystems. Such a situation is found in Lake Pavin ( [Michard et al., 1994] and [Viollier et al., 1995] ) and makes this lake a unique microbial habitat allowing the study of biologically mediated redox processes. With an intense in situ production of Fe and $\mathrm{Mn}$ oxides (Viollier, 1995) and the presence of $\mathrm{SO}_{4}^{2-}$ and $\mathrm{NO}_{3}^{-}$in the water column, chemical conditions potentially allow aerobic methanotrophy above the oxycline and anaerobic $\mathrm{CH}_{4}$ oxidation beneath the oxycline. Based on the characterization of microbial communities ( [Lehours et al., 2005] and [Lehours et al., 2007] ) and the utilization of a conservative tracer, Assayag et al. (2008) suggested that anaerobic $\mathrm{CH}_{4}$ oxidation might explain the apparent $\mathrm{CH}_{4}$ consumption in the mesolimnion of Lake Pavin. In order to numerically test the hypothesis of the $\mathrm{CH}_{4}$ consumption pathways in Lake Pavin, field $\mathrm{CH}_{4}$ oxidation rates were measured and a reactive transport model was developed. The model incorporates for the first time the $\mathrm{CH}_{4}$ oxidation pathways coupled to the reduction of $\mathrm{O}_{2}, \mathrm{NO}_{3}^{-}, \mathrm{SO}_{4}^{2-}, \mathrm{Mn}$ and $\mathrm{Fe}$ (hydr)oxides, with a set of classical primary and secondary redox reactions. In this study, the relative significance of the different $\mathrm{CH}_{4}$ sink pathways in the water column of Lake Pavin are discussed.

\section{Methods}




\subsection{Site description}

Lake Pavin (elevation $1197 \mathrm{~m}$ above the sea level) is located in the French Massif Central at $45^{\circ} 29.74 \prime \mathrm{N}$ and $2^{\circ} 53.28^{\prime} \mathrm{E}$ in a volcanic area. It is circular in shape and has a diameter of 750 $\mathrm{m}$ and an area of $0.44 \mathrm{~km}^{2}$. Its maximum depth is $92 \mathrm{~m}$. It is a crater lake characterized by the presence of two stratified layers: the upper layer (the mixolimnion) which extends from the surface to $60 \mathrm{~m}$ depth and is affected by fall and spring turnover, and the deepest layer (monimolimnion) below approximately $70 \mathrm{~m}$ depth is permanent (the major physical and chemical parameters do not change seasonally) and anoxic. A transition zone, the mesolimnion ( $c a$. 60-70 $\mathrm{m}$ depth), which separates the mixolimnion from the monimolimnion, is characterized by a strong increase in specific conductivity and by an increase in temperature of about $1{ }^{\circ} \mathrm{C}$.

Within the mixolimnion three different layers can be identified based on seasonal depth variations of dissolved $\mathrm{O}_{2}, \mathrm{pH}$, temperature and conductivity: (1) The epilimnion corresponds to the surface mixed layer, with seasonal variations in temperature and thickness $\left(0-20{ }^{\circ} \mathrm{C}\right.$ and 5-15 m), (2) the metalimnion ( $c a .15-20 \mathrm{~m}$ depth) is characterized by a steep temperature gradient, (3) the hypolimnion with a stable temperature close to $4{ }^{\circ} \mathrm{C}$ extends approximately from 20 to $60 \mathrm{~m}$ depth. Seasonal $\mathrm{O}_{2}$ depletion down to zero occurs at the bottom of the hypolimnion within the depth range of approximately 58 and $61 \mathrm{~m}$.

Fifteen tributaries, small or temporary, together with atmospheric precipitation contribute to surface water inputs (Table 1). Additional water supply comes from sublacustrine inputs (Table 1) to the mixolimnion (located at $54 \pm 2 \mathrm{~m}$ depth, typical surface runoff water) and to the monimolimnion (located at $89 \pm 2 \mathrm{~m}$ depth, typical mineral spring water) (Assayag et al., 2008). Biological diversity and activity has been described in [Quiblier-Lloberas et al., 1996] and [Colombet et al., 2006] and Lemarchand et al. (2006).

Table 1. Lake Pavin biogeochemical model: fixed parameters.

\begin{tabular}{|l|l|}
\hline Parameter & Value \\
\hline$d_{\mathrm{Fep}}$ & $5 \mu \mathrm{m}^{\mathrm{a}}$ \\
\hline$d_{\mathrm{Mnp}}$ & $5 \mu \mathrm{m}^{\mathrm{a}}$ \\
\hline$d_{\mathrm{POC}}$ & $10 \mu \mathrm{m}$ \\
\hline$d_{\mathrm{POC}}($ March-April) & $100 \mu \mathrm{m}$ \\
\hline$\rho_{\mathrm{Fep}}, \rho_{\text {Mnp }}$ & $2820 \mathrm{~kg} \mathrm{~m}^{-3} \underline{\mathrm{a}}$ \\
\hline$\rho_{\mathrm{POC}}$ & $1500 \mathrm{~kg} \mathrm{~m}^{-3 \underline{\mathrm{b}}}$ \\
\hline$Q \_$mixolimnion $(54 \mathrm{~m} \mathrm{depth})$ & $1728 \mathrm{~m}^{3} \mathrm{day}^{-1} \underline{\mathrm{c}}$ \\
\hline$Q \_$monimolimnion $(89 \mathrm{~m} \mathrm{depth})$ & $138 \mathrm{~m}^{3} \mathrm{day}^{-1} \underline{\mathrm{c}}$ \\
\hline$\left[\mathrm{Fe}^{2+}\right]_{-}$monimolimnion & $0.56 \mathrm{mmol} \mathrm{L}^{-1}$ \\
\hline$\left[\mathrm{Mn}^{2+}\right]_{-}$monimolimnion & $0.044 \mathrm{mmol} \mathrm{L}^{-1}$ \\
\hline$\left[\mathrm{SO}_{4}^{2-}\right]_{\text {input }}$ & $0.013 \mathrm{mmol} \mathrm{L}^{-1}$ \\
\hline$\left[\mathrm{NO}_{3}^{-}\right]_{\text {input }}$ & $0.03 \mathrm{mmol} \mathrm{L}^{-1}$ \\
\hline$\left[\mathrm{O}_{2}\right]_{\text {input }}$ & $0.33 \mathrm{mmol} \mathrm{L}^{-1}$ \\
\hline$F_{-} \mathrm{CH}_{-} \_40 \mathrm{~m}$ & $5.8 \times 10^{-4} \mathrm{~mol} \mathrm{~m}^{-2} \mathrm{day}^{-1} \underline{\mathrm{d}}$ \\
\hline
\end{tabular}




\begin{tabular}{|l|l|}
\hline Parameter & Value \\
\hline$F_{-} \mathrm{CH} 4 \_92 \mathrm{~m}$ & $2.6 \times 10^{-3} \mathrm{~mol} \mathrm{~m}^{-2} \mathrm{day}^{-1} \underline{\mathrm{d}}$ \\
\hline$F_{-} \mathrm{Fe}^{2+}$ & $9.21 \times 10^{-4} \mathrm{~mol} \mathrm{~m}^{-2} \mathrm{day}^{-1} \underline{\mathrm{e}}$ \\
\hline$F_{-} \mathrm{Mn}^{2+}$ & $1.39 \times 10^{-6} \mathrm{~mol} \mathrm{~m}^{-2} \mathrm{day}^{-15 \underline{\mathrm{e}}}$ \\
\hline$F_{-} \mathrm{NH}_{4}^{+}$ & $4.13 \times 10^{-4} \mathrm{~mol} \mathrm{~m}^{-2} \mathrm{day}^{-1} \underline{\mathrm{e}}$ \\
\hline$F_{-\mathrm{Fep}}$ & $6 \times 10^{-5} \mathrm{~mol} \mathrm{~m}^{-2} \mathrm{day}^{-1 \underline{\mathrm{f}}}$ \\
\hline$F_{-\mathrm{Mnp}}$ & $1.6 \times 10^{-5} \mathrm{~mol} \mathrm{~m}^{-2} \mathrm{day}^{-1 \underline{\mathrm{f}}}$ \\
\hline$Q$ & $1019-2630 \mathrm{~m}^{3} \mathrm{day}^{-1} \underline{\mathrm{d}}$ \\
\hline$d$ & $1-16 \mathrm{~m}^{\underline{\mathrm{d}}}$ \\
\hline
\end{tabular}

$d_{\mathrm{Fep}}, d_{\mathrm{Mnp}}, d_{\mathrm{POC}}-$ Diameter of particulate Fe, particulate Mn and particulate organic $\mathrm{C}$, respectively. $d$ - Diving depth range of the tributaries. $\rho_{\mathrm{Fep}}, \rho_{\mathrm{Mnp}} \rho_{\mathrm{POC}}-$ Density of particulate Fe, Mn and organic C. $Q \_$mixolimnion, $Q \_$monimolimnion - Flow rate of the mixolimnion and monimolimnion sublacustrine inflows (Assayag et al., 2008). $Q$ - Flow rate ranges of the small tributaries determined in field campaigns from June 2006 to June 2007.[ $\left.\mathrm{SO}_{4}^{2-}\right]_{\text {input }}\left[\mathrm{NO}_{3}^{-}\right]_{\text {input }},\left[\mathrm{O}_{2}\right]_{\text {input }}-$ Average concentrations of $\mathrm{SO}_{4}^{2-}, \mathrm{NO}_{3}^{-}$and

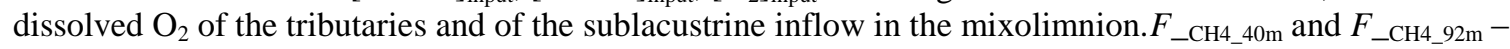
Methane fluxes at 40 and $92 \mathrm{~m}$ depth calculated according to Fick's law (Boudreau, 1997) with $\mathrm{CH}_{4}$ concentration profiles in sediments collected at 40 and $92 \mathrm{~m}$ depth. $F_{-} \mathrm{Fe}^{2+}, F_{-} \mathrm{Mn}^{2+}, F_{-} \mathrm{NH}_{4}^{+}$- Fluxes of dissolved Fe, Mn and $\mathrm{NH}_{4}^{+}$determined according to Fick's law with data from 1994 (Viollier, 1995).F_Fep, $F_{- \text {Mnp }}$ - Fluxes of particulate Fe and Mn from field data collected in 1994 (Viollier,

1995. $\left[\mathrm{Fe}^{2+}\right]$ monimolimnion, $\left[\mathrm{Mn}^{2+}\right]$ monimolimnion - Concentration of dissolved $\mathrm{Fe}$ and $\mathrm{Mn}$ in the monimolimnion sublacustrine input. Data from previous field campaigns (Viollier et al., 1997.

${ }^{a}$ Based on Taillefert and Gaillard (2002).

${ }^{\mathrm{b}}$ Based on Pourriot and Meybeck (1995.

${ }^{\mathrm{c}}$ Assayag et al. (2008)

${ }^{\mathrm{d}}$ From this study.

${ }^{\mathrm{e}}$ From field data collected in September 1993 (Viollier, 1995).

${ }^{\mathrm{f}}$ From field data collected in 1994 (Viollier, 1995).

\subsection{Data set: vertical concentration profiles from multiple campaigns}

From June 2006 to June 2007, monthly water samples were taken along a vertical profile near the centre of the lake. Additionally, settling particles were collected from May 2006 to May 2007 with sediment traps at $23 \mathrm{~m}$ depth in order to determine particulate fluxes (Thiam et al., in preparation). Particles were collected approximately every month, except during winter 2006 (sediment traps were not sampled from November 2006 to mid March 2007). Sodium azide crystals were used as poison in order to prevent particle biodegradation. Immediately after sampling, settled particles were filtered on GF/F Whatmann membranes under a $\mathrm{N}_{2}$ atmosphere.

Temperature, conductivity and dissolved $\mathrm{O}_{2}$ concentration were measured with a Seabird Seacat Profiler SBE19. Depth profiles of $\mathrm{NO}_{3}^{-}$and $\mathrm{SO}_{4}^{2-}$ concentrations were determined monthly. Methane concentration in the water column was determined in June 2006, September 2006, February 2007, April 2007, May 2007, June 2007 and July 2007 (see Section 2.2.1). Depth profiles of dissolved organic C were measured in October 2006, May and June 2007 according to Albéric et al. (2000). Depth profiles of $\mathrm{NH}_{4}^{+}$, total orthophosphates, dissolved $\mathrm{Fe}$ and $\mathrm{Mn}$, total $\mathrm{H}_{2} \mathrm{~S}$ and alkalinity were also determined during 
the same field campaigns. Additionally, chemical $\left(\mathrm{NO}_{3}^{-}\right.$and $\mathrm{SO}_{4}^{2-}$ ) and physical (flow rate, temperature, conductivity) parameters were measured monthly in tributaries discharging into the lake from June 2006 to June 2007.

\subsubsection{Methane concentrations in the water column and in sediment pore water}

Water samples for $\mathrm{CH}_{4}$ analysis were collected with an automatic laboratory-made $1 \mathrm{~L}$ syringe sampler along a vertical profile near the centre of the lake. Water from the oxic mixolimnion (from the surface to $55 \mathrm{~m}$ depth) was collected into serum bottles (100 $\mathrm{mL}$ ) by filling them to overflowing, sealing and poisoning with $1 \mathrm{~mL}$ of $0.5 \mathrm{~g} \mathrm{~L}^{-1} \mathrm{HgCl}_{2}$. A $30 \mathrm{~mL} \mathrm{~N}_{2}$ headspace was created before analysis, as described in Abril and Iversen (2002). In the $\mathrm{CH}_{4^{-}}$ rich monimolimnion (from $55 \mathrm{~m}$ to $90 \mathrm{~m}$ ), a different sampling procedure was used in order to limit the loss of $\mathrm{CH}_{4}$ due to depressurization: $30 \mathrm{~mL}$ of water from the sampling syringe were rapidly transferred with a needle through the butyl cap of a pre-weighed $100 \mathrm{~mL}$ serum bottles (pre flushed with $\mathrm{N}_{2}$ gas). With this procedure, most of the depressurization occurred in the vial and the loss of $\mathrm{CH}_{4}$ could be minimized. Methane concentrations were quantified using a gas chromatograph (GC) equipped with flame ionization detector (FID), according to Abril and Iversen (2002).

Site sediment cores from 40 and $92 \mathrm{~m}$ depth were sampled with a UWITEC corer $(D 9 \times L 60$ $\mathrm{cm}$ ) in order to determine $\mathrm{CH}_{4}$ concentration profiles in sediment pore waters for June 2007. Cores were laterally sub-sampled at $2 \mathrm{~cm}$ intervals with $2 \mathrm{~mL}$ syringe-based pistons, through pre-drilled holes in the tube corer (holes were initially closed with water-proof tape). Sediment sub-samples were then transferred into pre-weighed $100 \mathrm{~mL}$ serum bottles containing $10 \mathrm{~mL}$ of $10 \mathrm{~N} \mathrm{NaOH}$. The vials were then sealed rapidly with rubber stoppers and Al crimps. They were then weighed and shaken vigorously. The $\mathrm{CH}_{4}$ concentration in the equilibrated gas phase was determined as for water samples. Methane concentration in pore waters was calculated using the water content (determined gravimetrically on duplicate cores). Methane fluxes from the sediment layer at 40 and $92 \mathrm{~m}$ were calculated according to Fick's law (Boudreau, 1997; see Section 3.3 in this manuscript, Table 1).

\subsubsection{In situ methane oxidation rates}

In order to determine in situ anaerobic $\mathrm{CH}_{4}$ oxidation rates, water samples were collected from 60,61 and $62 \mathrm{~m}$ depths, transferred to serum bottles and incubated at their respective depths using nylon bags attached to a float-wire cable. Additionally, some vials from each depth were poisoned with $\mathrm{HgCl}_{2}\left(1 \mathrm{~mL}\right.$ of $\left.0.5 \mathrm{~g} \mathrm{~L}^{-1} \mathrm{HgCl}_{2}\right)$, in order to inhibit the activity of $\mathrm{CH}_{4}$ oxidizers, representing a reference for potential abiotic evolution. Sample bottles were removed from the water column in May 2007. Rates were calculated from the difference in $\mathrm{CH}_{4}$ concentrations between October 2006 and May 2007.

Aerobic $\mathrm{CH}_{4}$ oxidation rates were determined at variable $\mathrm{CH}_{4}$ concentrations. Three litres of water were collected at $50 \mathrm{~m}$ depth and about $800 \mathrm{~mL}$ were transferred to three $1 \mathrm{~L}$ glass vials containing $200 \mathrm{~mL}$ of air headspace. A known amount of pure $\mathrm{CH}_{4}$ was then introduced in the headspace and the vials were vigorously shaken in order to equilibrate the $\mathrm{CH}_{4}$ in the water and the gas mixture. Three different $\mathrm{CH}_{4}$ concentrations were tested: $60 \times 10^{-9}, 171 \times 10^{-9}$ and $352 \times 10^{-9} \mathrm{~mol} \mathrm{~L}^{-1}$, covering the range of water $\mathrm{CH}_{4}$ concentrations in the upper layers of the mixolimnion (from the surface to approximately $55 \mathrm{~m}$ ). Water samples were then siphoned into $100 \mathrm{~mL}$ serum vials that were further sealed. In the assays, $\mathrm{O}_{2}$ was not limiting. Eight bottles for each $\mathrm{CH}_{4}$ concentration were incubated at in situ temperature. At 0,22, 36 
and $51 \mathrm{~h}$, duplicate bottles were poisoned with $\mathrm{HgCl}_{2}$, and further analyzed for $\mathrm{CH}_{4}$ initial concentration as described earlier. Rates of aerobic $\mathrm{CH}_{4}$ oxidation for each $\mathrm{CH}_{4}$ concentration were calculated as the slope of the decrease in $\mathrm{CH}_{4}$ concentration with time. The first order constant of the aerobic $\mathrm{CH}_{4}$ oxidation kinetics was subsequently determined and used in the reactive transport model (see below).

\subsection{Model description}

\subsubsection{Overview}

A reactive-transport model that accounts for spatial and temporal distribution of chemical species in the lake water column was developed from AQUASIM software (Reichert, 1998).

In the model, dissolved and particulate species are transported through the water column by vertical mixing. Particulate substances are also transported by sedimentation. Moreover, dissolved species are brought to the lake by inflows from small tributaries and by sublacustrine inputs. Dissolved and particulate species are allowed to react in multiple biogeochemical pathways specified through reaction rate equations.

\subsubsection{Modelled species (state variables)}

The model considers the following state variables: $\mathrm{CH}_{4}$, dissolved and particulate $\mathrm{Fe}$ and $\mathrm{Mn}$, dissolved $\mathrm{O}_{2}, \mathrm{NO}_{3}^{-}, \mathrm{SO}_{4}^{2-}, \mathrm{NH}_{4}^{+}$, total dissolved sulfide, dissolved and particulate organic $\mathrm{C}$ (DOC and POC, respectively), total orthophosphates and total dissolved $\mathrm{CO}_{2}$ (DIC). The elemental composition of organic particles is similar to the one reported by Sigg (1985)

for lake Constance: $\left(\mathrm{CH}_{2} \mathrm{O}\right)_{113}\left(\mathrm{NH}_{3}\right)_{15}\left(\mathrm{H}_{3} \mathrm{PO}_{4}\right)$.

\subsubsection{Governing differential equations}

Biogeochemical and physical processes, expressed by a set of partial differential transportreaction equations (Reichert, 1998), are implemented in the AQUASIM code. The following equations are solved for each dissolved and particulate state variable, respectively.(1)

$$
\begin{aligned}
& \frac{\partial C}{\partial t}=\frac{\partial}{A \partial z}\left(A K_{z} \frac{\partial C}{\partial z}\right)-\frac{\partial}{A \partial z}(Q C)+r_{C}+\frac{q}{A} C_{\text {in }} \text { (2) } \\
& \frac{\partial X}{\partial t}=\frac{\partial}{A \partial z}\left(A K_{z} \frac{\partial X}{\partial z}\right)-\frac{\partial}{A \partial z}(Q X)+r_{X}+\frac{\partial}{\partial z}\left(V_{s e d} X\right)
\end{aligned}
$$

where $C$ is the concentration of a dissolved compound $\left(\mathrm{M} \mathrm{L}^{-3}\right), X$ is the concentration of a particulate compound $\left(\mathrm{M} \mathrm{L}^{-3}\right), t$ is the time $(\mathrm{T}), z$ is the vertical coordinate pointing downwards ( $z=0$ at the lake surface) (L), $A$ is the cross-sectional area of the lake $\left(\mathrm{L}^{2}\right), K_{z}$ is the vertical mixing coefficient $\left(\mathrm{L}^{2} \mathrm{~T}^{-1}\right), r$ are the transformation rates $\left(\mathrm{M} \mathrm{L}^{-3} \mathrm{~T}^{-1}\right), Q$ is the vertical discharge induced by water inflows in the lake depth $\left(\mathrm{L}^{3} \mathrm{~T}^{-1}\right), C_{\text {in }}$ is the inflow concentration of a dissolved compound $\left(\mathrm{M} \mathrm{L}^{-3}\right), V_{\text {sed }}$ is the sedimentation velocity $\left(\mathrm{L} \mathrm{T}^{-1}\right), q$ is the discharge of water per unit depth into the lake $\left(\mathrm{L}^{2} \mathrm{~T}^{-1}\right)$. 
In both equations, the first term describes mixing due to eddy diffusion, the second term refers to advection in the water column resulting from inflows, and the third term describes the net effect of all transformations processes. In Eq. (1), the fourth term is related to inflows, whereas in Eq. (2), it describes sedimentation of particulate species through the water column. Other boundary conditions are the benthic fluxes of iron, manganese and ammonium from sediment pore waters, calculated according to Fick's law (Boudreau, 1997) and field data from September 1993 (Viollier, 1995). The set of partial differential equations is solved numerically with a vertical resolution of $1 \mathrm{~m}$ (Reichert, 1998).

\subsubsection{Physical processes}

\subsubsection{Vertical mixing}

Monthly vertical eddy diffusion coefficient $\left(K_{z}\right)$ profiles are calculated based on temperature and conductivity profiles. Water column density and Brunt-Väisälä Frequency $\left(N^{2}\right)$ are calculated according to expressions reported by Aeschbag-Hertig et al. (2002). The vertical resolution is $1 \mathrm{~m}$. The following expression is used to derive $K_{z}$ values:(3) $K_{Z}=\alpha\left(N^{2}\right)^{-q}$ where $K_{z}$ is the vertical eddy diffusion coefficient $\left(\mathrm{M}^{2} \mathrm{~T}^{-1}\right)$ and $N^{2}$ is the Brunt-Väisälä $\left(\mathrm{T}^{-2}\right)$ frequency

given by $N^{2}=-\frac{g \partial \rho}{\rho \partial Z}$

The parameter $q$ is set to 0.5 as discussed in Aeschbag-Hertig et al. (2002) for Lake Pavin. Eddy diffusion coefficient values in Lake Pavin spread over 4 orders of magnitude. The smallest values are calculated for the mesolimnion where $K_{z}$ decreases to nearly $10^{-8} \mathrm{~m}^{2} \mathrm{~s}^{-1}$.

\subsubsection{Advection}

Advective fluxes are directly related to the sublacustrine inflows. In the mixolimnion, $\mathrm{NO}_{3}^{-}$, $\mathrm{SO}_{4}^{2-}$ and $\mathrm{O}_{2}$ are constantly brought to the water column. In the monimolimnion, the mineral spring located at $89 \pm 2$ m depth adds dissolved Fe and Mn to the lake (Viollier et al., 1997) (Table 1). Advection appears to be fairly weak with average rates from few centimeters to meters per year when normalized to the lake cross section (Michard et al., 1994). In the epilimnion, advection is also impacted by the small tributaries (Table 1). The equal-density level is used to determine the diving depth of those lateral inputs.

\subsubsection{Sedimentation}

Sedimentation rate of particulate Fe, $\mathrm{Mn}$ and organic $\mathrm{C}$ are calculated according to Stokes's law (Taillefert and Gaillard, 2002). Monthly sedimentation rate profiles for these species are calculated based on water column density, water viscosity, size and density of the particles. Average density and diameter of particulate Fe, $\mathrm{Mn}$ and organic $\mathrm{C}$ are presented in Table 1. The increase of the average diameter of the organic $\mathrm{C}$ particles from middle March to middle April is taken into account. It corresponds to Diatom spring bloom (main species: Aulacoseira italica, Asterionella formosa) and aggregation-sedimentation processes leading to an increase 
in sedimentation velocity (Carrias, 1996). The calculated sedimentation velocities of particulate $\mathrm{Fe}$ and $\mathrm{Mn}$ ranged from $0.55 \mathrm{~m} \mathrm{day}^{-1}$ in lower water layers (for all months) to 0.55-0.9 $\mathrm{m} \mathrm{day}^{-1}$ in the epilimnion (values for April 2007 and July 2006, respectively).

Sedimentation velocities of POC of $0.2-40 \mathrm{~m} \mathrm{day}^{-1}$ are described in the literature ( [Pourriot and Meybeck, 1995] and [Omlin et al., 2001] ). The calculated POC sedimentation rates in this work ranged from $1.5 \mathrm{~m} \mathrm{day}^{-1}$ in the lower water layers to $1.7-2.3 \mathrm{~m} \mathrm{day}^{-1}$ in the upper water layers (values for April 2007 and June 2006, respectively). From March 2007 to April 2007, particulate organic $C$ sedimentation rates ranged from $6 \mathrm{~m} \mathrm{day}^{-1}$ for layers below the hypolimnion to around 6-6.4 $\mathrm{m} \mathrm{day}^{-1}$ in the epi- and metalimnion.

Additionally, particulate Fe and Mn fluxes from the surface of the lake are also included in the model. Data were measured elsewhere $\left(6 \times 10^{-5}\right.$ and $1.6 \times 10^{-5} \mathrm{~mol} \mathrm{~m}^{-2} \mathrm{day}^{-1}$ for particulate Fe and particulate Mn, respectively, from the 1994 data set published in Viollier et al., 1995) (Table 1).

\subsubsection{Gas exchange at the lake surface}

Dissolved $\mathrm{O}_{2}, \mathrm{CO}_{2}$ and $\mathrm{CH}_{4}$ exchange rates are considered as boundary conditions at the lake surface. The dissolved $\mathrm{O}_{2}$ flux, given by Eq. (5), is proportional to the difference between $\mathrm{O}_{2}$ concentration $\left(\mathrm{O}_{2 \_Z=0}\right)$ at the lake surface and the saturation concentration $\left(\mathrm{O}_{2}\right.$ solubility $)$ corrected to the elevation above sea level:(5) $F_{\mathrm{O} 2}=k \times\left(\mathrm{O}_{2 \_ \text {solublity }}-\mathrm{O}_{2 \_Z=0}\right)$ where $F_{\mathrm{O} 2}$ is the $\mathrm{O}_{2}$ flux $\left(\mathrm{mol} \mathrm{m}{ }^{-2} \mathrm{day}^{-1}\right.$ ) and $k$ is the gas exchange velocity, which is proportional to the square of wind velocity $\left(\mathrm{m} \mathrm{day}^{-1}\right.$ ) (Liss and Merllivat, 1986). $k$ equals $1 \mathrm{~m}^{-1 a y}{ }^{-1} . \mathrm{O}_{2 \_} \mathrm{Z}=0$ and $\mathrm{O}_{2 \_ \text {solubility }}$ are given in $\mathrm{mol} \mathrm{m}^{-3}$.

The partial pressure of $\mathrm{O}_{2}$ in air is assumed constant and equal to 0.21 times the atmospheric pressure (about 880 mbar) at the elevation of the lake.

The dependence of the saturation concentration of $\mathrm{O}_{2}\left(\mathrm{~mol} \mathrm{~L}^{-1}\right)$ on temperature is given by the following expression:(6) $\mathrm{O}_{2}=10^{\left\{-47.238+\frac{2291}{8+273}+14.403 \log (T+273)\right\}} \times 0.2095 \exp (-0.000119 H)$ where $T$ is the water temperature in ${ }^{\circ} \mathrm{C}$ at the lake surface and $H$ describes the elevation of the lake above sea level $(1200 \mathrm{~m})$.

The $\mathrm{CO}_{2}$ flux across the water-air interface is also proportional to the difference of the current $\mathrm{CO}_{2}\left(\mathrm{CO}_{2 \_} \mathrm{Z}=0\right)$ at the lake surface and the saturation $\left(\mathrm{CO}_{2 \_ \text {solubility }}\right)$ value. (7) $F_{\mathrm{CO} 2}=k \times\left(\mathrm{CO}_{2 \_ \text {solubility }}-\mathrm{CO}_{2 Z Z=0}\right)$ where $F_{\mathrm{CO} 2}$ is the $\mathrm{CO}_{2}$ flux $\left(\mathrm{mol} \mathrm{m}^{-2}\right.$ day $\left.^{-1}\right), k(1 \mathrm{~m}$ day $^{-1}$ ) is the gas exchange velocity (the same as Eq. (5)). $\mathrm{CO}_{2 \_} Z=0$ and $\mathrm{CO}_{2}$ solubility are given in mol m${ }^{-3} \cdot \mathrm{CO}_{2} Z=0$ is calculated from the DIC (dissolved inorganic C), the water $\mathrm{pH}$ and $K_{a 1}$ and $K_{a 2}$ (dissociation constants).

The partial pressure of $\mathrm{CO}_{2}$ in air is assumed constant and equal to $3.7 \times 10^{-4}$ the atmospheric pressure at the elevation of the lake. The saturation concentration of $\mathrm{CO}_{2}$ is given by the following equation (Robie et al., 1978):(8) $\mathrm{CO}_{2 \text { _solubility }}=0.001 \times(25.05-$

$0.8249 T+0.001132 T^{2}$ ) where $\mathrm{CO}_{2}$ solubility is given in $\mathrm{mol} \mathrm{m}^{-3}$ and $T$ is the water temperature in ${ }^{\circ} \mathrm{C}$ at the lake surface.

The dissolved $\mathrm{CH}_{4}$ flux ( $\mathrm{mol} \mathrm{m}{ }^{-2} \mathrm{day}^{-1}$ ) is given by the following expression:(9) $F_{\mathrm{CH} 4}=k \times\left(\mathrm{CH}_{4 \_ \text {solubility }}-\mathrm{CH}_{4 \_Z=0}\right)$ where $(10) \mathrm{CH}_{4 \_ \text {solubility }}=K_{H} P_{\mathrm{CH} 4}$ with $K_{H}$ is the Henry's law constant (mol L ${ }^{-1}$ atm $^{-1}$; Sanders, 1999) 
$K_{H}=1.4 \times 10^{-3} \operatorname{Exp}\left[-1700 \times\left(\frac{1}{T+273}-\frac{1}{298.15}\right)\right]$

and $P_{\mathrm{CH} 4}$ is the $\mathrm{CH}_{4}$ partial pressure in the air (approximately $2 \times 10^{-6}$ atm).

\subsubsection{Biogeochemical reactions}

\subsubsection{Redox reactions}

The set of reactions used in the model is adapted from those proposed by [Hunter et al., 1998] , [Van Cappellen and Wang, 1996] and [Omlin et al., 2001] and Reichert et al. (2001) for surface and subsurface environments. Table 2 gives an overview of the biogeochemical processes used in the model. The model includes the organic $\mathrm{C}$ export reaction (Reaction (1)), primary redox reactions, i.e. organic matter mineralisation of dissolved and particulate organic C (Reactions (2)-(7)) and the secondary redox reactions (Reactions (8)-(19)). Primary reactions include aerobic respiration (Reaction (2)), denitrification (Reaction (3)), Mn oxide reduction (Reaction (4)), Fe (hydr)oxide reduction (Reaction (5)), $\mathrm{SO}_{4}^{2-}$ reduction (Reaction (6)) and methanogenesis (Reaction (7)). Oxidation of organic matter produces reduced species such as $\mathrm{Mn}^{2+}, \mathrm{Fe}^{2+}$ and $\mathrm{CH}_{4}$ which may participate in secondary redox reactions. The model considers the following secondary reactions: nitrification (Reaction (18)), Fe oxidation (Reaction (13)), Mn oxidation (Reaction (16)), Fe oxidation through reaction with Mn oxides (Reaction (14)), Fe reduction coupled to denitrification (ferrous denitrification, Reaction (15)), sulfide oxidation (Reaction (19)), nitrification coupled to Mn oxides reduction (17). The following $\mathrm{CH}_{4}$ consumption pathways are integrated in the model: aerobic $\mathrm{CH}_{4}$ oxidation (Reaction (8)) and anaerobic $\mathrm{CH}_{4}$ oxidation associated with denitrification (Reaction (9)), $\mathrm{Mn}$ (Reaction (10)), $\mathrm{Fe}\left(\right.$ Reaction (11)) and $\mathrm{SO}_{4}^{2-}$ reduction (Reaction (12)). 
Table 2. Lake Pavin biogeochemical model: set of reactions.

Organic carbon export - Reaction (1)

$\mathrm{HCO}_{3}^{-}+\frac{15}{113} \mathrm{NO}_{3}^{-}+\frac{1}{113} \mathrm{HPO}_{4}^{2-}+\frac{15}{113} \mathrm{H}_{2} \mathrm{O}+\frac{130}{113} \mathrm{H}^{+} \rightarrow\left(\mathrm{CH}_{2} \mathrm{O}\right)\left(\mathrm{NH}_{3}\right)_{\frac{15}{15}}\left(\mathrm{H}_{3} \mathrm{PO}_{4}\right)_{\frac{1}{\pi 1}}+\frac{143}{113} \mathrm{O}$

Primary reactions

Reaction (2)

$\left(\mathrm{CH}_{2} \mathrm{O}\right)\left(\mathrm{NH}_{3}\right)_{\frac{15}{113}}\left(\mathrm{H}_{3} \mathrm{PO}_{4}\right)_{\frac{11}{113}}+\frac{143}{113} \mathrm{O}_{2} \rightarrow \mathrm{HCO}_{3}^{-}+\frac{15}{113} \mathrm{NO}_{3}^{-}+\frac{1}{113} \mathrm{HPO}_{4}^{2-}+\frac{15}{113} \mathrm{H}_{2} \mathrm{O}+\frac{130}{113} \mathrm{H}^{-}$

Reaction (3)

$\left(\mathrm{CH}_{2} \mathrm{O}\right)\left(\mathrm{NH}_{3}\right)_{\frac{15}{115}}\left(\mathrm{H}_{3} \mathrm{PO}_{4}\right)_{\frac{1}{113}}+\frac{497}{565} \mathrm{NO}_{3}^{-} \rightarrow \mathrm{HCO}_{3}^{-}+\frac{286}{565} \mathrm{~N}_{2}+\frac{1}{113} \mathrm{HPO}_{4}^{2-}+\frac{361}{565} \mathrm{H}_{2} \mathrm{O}+\frac{78}{565} \mathrm{H}$

Reaction (4)

$\left(\mathrm{CH}_{2} \mathrm{O}\right)\left(\mathrm{NH}_{3}\right)_{\frac{15}{113}}\left(\mathrm{H}_{3} \mathrm{PO}_{4}\right)_{\frac{1}{113}}+2 \mathrm{MnO}_{2}+\frac{352}{113} \mathrm{H}^{+} \rightarrow \mathrm{HCO}_{3}^{-}+\frac{15}{113} \mathrm{NH}_{4}^{+}+\frac{1}{113} \mathrm{HPO}_{4}^{2-}+2 \mathrm{H}_{2} \mathrm{C}$

Reaction (5)

$\left(\mathrm{CH}_{2} \mathrm{O}\right)\left(\mathrm{NH}_{3}\right)_{\frac{55}{113}}\left(\mathrm{H}_{3} \mathrm{PO}_{4}\right)_{\frac{1}{113}}+4 \mathrm{FeOOH}+\frac{804}{113} \mathrm{H}^{+} \rightarrow \mathrm{HCO}_{3}^{-}+\frac{15}{113} \mathrm{NH}_{4}^{+}+\frac{1}{113} \mathrm{HPO}_{4}^{2-}+6 \mathrm{H}$

Reaction (6)

$\left(\mathrm{CH}_{2} \mathrm{O}\right)\left(\mathrm{NH}_{3}\right)_{\text {柴 }}\left(\mathrm{H}_{3} \mathrm{PO}_{4}\right)_{\frac{1}{113}}+\frac{1}{2} \mathrm{SO}_{4}^{2-} \rightarrow \mathrm{HCO}_{3}^{-}+\frac{15}{113} \mathrm{NH}_{4}^{+}+\frac{1}{113} \mathrm{HPO}_{4}^{2-}+\frac{1}{2} \mathrm{HS}^{-}+\frac{43.5}{113} \mathrm{H}^{-}$

Reaction (7)

$\left(\mathrm{CH}_{2} \mathrm{O}\right)\left(\mathrm{NH}_{3}\right)_{\frac{15}{115}}\left(\mathrm{H}_{3} \mathrm{PO}_{4}\right)_{\frac{1}{11.3}}+\frac{1}{2} \mathrm{H}_{2} \mathrm{O} \rightarrow \frac{1}{2} \mathrm{HCO}_{3}^{-}+\frac{15}{113} \mathrm{NH}_{4}^{+}+\frac{1}{113} \mathrm{HPO}_{4}^{2-}+\frac{1}{2} \mathrm{CH}_{4}+\frac{43.5}{113} \mathrm{H}$

\section{Secondary reactions}

Reaction (8) $-\mathrm{CH}_{4}+2 \mathrm{O}_{2} \rightarrow \mathrm{HCO}_{3}^{-}+\mathrm{H}^{+}+\mathrm{H}_{2} \mathrm{O}$

Reaction (9) $-\mathrm{CH}_{4}+1.6 \mathrm{NO}_{3}^{-}+0.6 \mathrm{H}^{+} \rightarrow \mathrm{HCO}_{3}^{-}+0.8 \mathrm{~N}_{2}+1.8 \mathrm{H}_{2} \mathrm{O}$

Reaction (10) $-\mathrm{CH}_{4}+4 \mathrm{MnO}_{2}+7 \mathrm{H}^{+} \rightarrow \mathrm{HCO}_{3}^{-}+4 \mathrm{Mn}^{2+}+5 \mathrm{H}_{2} \mathrm{O}$

Reaction (11) $-\mathrm{CH}_{4}+8 \mathrm{FeOOH}+15 \mathrm{H}^{+} \rightarrow \mathrm{HCO}_{3}^{-}+8 \mathrm{Fe}^{2+}+13 \mathrm{H}_{2} \mathrm{O}$

Reaction (12) $-\mathrm{CH}_{4}+\mathrm{SO}_{4}^{2-} \rightarrow \mathrm{HCO}_{3}^{-}+\mathrm{HS}^{-}+\mathrm{H}_{2} \mathrm{O}$

Reaction $(13)-4 \mathrm{Fe}^{2+}+\mathrm{O}_{2}+6 \mathrm{H}_{2} \mathrm{O} \rightarrow 4 \mathrm{FeOOH}+8 \mathrm{H}^{+}$

Reaction $(14)-2 \mathrm{Fe}^{2+}+\mathrm{MnO}_{2}+2 \mathrm{H}_{2} \mathrm{O} \rightarrow 2 \mathrm{FeOOH}+\mathrm{Mn}^{2+}+2 \mathrm{H}^{+}$

Reaction $(15)-5 \mathrm{Fe}^{2+}+\mathrm{NO}_{3}^{-}+7 \mathrm{H}_{2} \mathrm{O} \rightarrow 0.5 \mathrm{~N}_{2}+5 \mathrm{FeOOH}+9 \mathrm{H}$

Reaction $(16)-2 \mathrm{Mn}^{2+}+\mathrm{O}_{2}+2 \mathrm{H}_{2} \mathrm{O} \rightarrow 2 \mathrm{MnO}_{2}+4 \mathrm{H}^{+}$

Reaction (17) $-\mathrm{NH}_{4}^{+}+4 \mathrm{MnO}_{2}+6 \mathrm{H}^{+} \rightarrow \mathrm{NO}_{3}^{-}+4 \mathrm{Mn}^{2+}+5 \mathrm{H}_{2} \mathrm{O}$

Reaction (18) $-\mathrm{NH}_{4}^{+}+2 \mathrm{O}_{2} \rightarrow \mathrm{NO}_{3}^{-}+2 \mathrm{H}^{+}+\mathrm{H}_{2} \mathrm{O}$

Reaction (19) $-\mathrm{H}_{2} \mathrm{~S}+2 \mathrm{O}_{2} \rightarrow \mathrm{SO}_{4}^{2-}+2 \mathrm{H}^{+}$

All the process rates are given in Table 3. The degradation of dissolved and particulate organic $\mathrm{C}$ is driven by microbially mediated processes. One appropriate expression for the dependence of organic $\mathrm{C}$ degradation on the electron acceptor concentration, such as 
dissolved $\mathrm{O}_{2}$ or $\mathrm{NO}_{3}^{-}$, is the Monod rate law (Van Cappellen et al., 1993 and [Boudreau, 1997] ). The presence of some oxidants may inhibit other metabolic pathways. Inhibition by oxidants is represented by an additional term in rate Eqs. (13)-(27) ( [Boudreau, 1997] and [Regnier et al., 2006] ). Once the concentration of the inhibitory species increases, the value of the inhibition term decreases and the effective rate decreases as well. The use of the limiting and inhibition functions in the model provides a direct coupling between the transformation processes and multiple species. The rate of methanogenesis (Eqs. (17) and (23)) is modelled as being inhibited by all oxidants. The same principle of inhibition terms is applied to the $\mathrm{CH}_{4}$ oxidation kinetics. Calculation of the standard Gibbs energy of Reactions (8)-(12) showed that the most energetically favourable pathway is the $\mathrm{CH}_{4}$ aerobic oxidation, followed by denitrification, $\mathrm{Mn}, \mathrm{Fe}$ and $\mathrm{SO}_{4}^{2-}$ reductions. Secondary redox reactions (Reactions (11)-(14), Reactions (16) and (19), Table 2) are represented by bimolecular rate law (Table 3), with apparent rate coefficients ( [Hunter et al., 1998] and [Smith and Jaffé, 1998] ). 
Table 3. Lake Pavin biogeochemical model: kinetic equations.

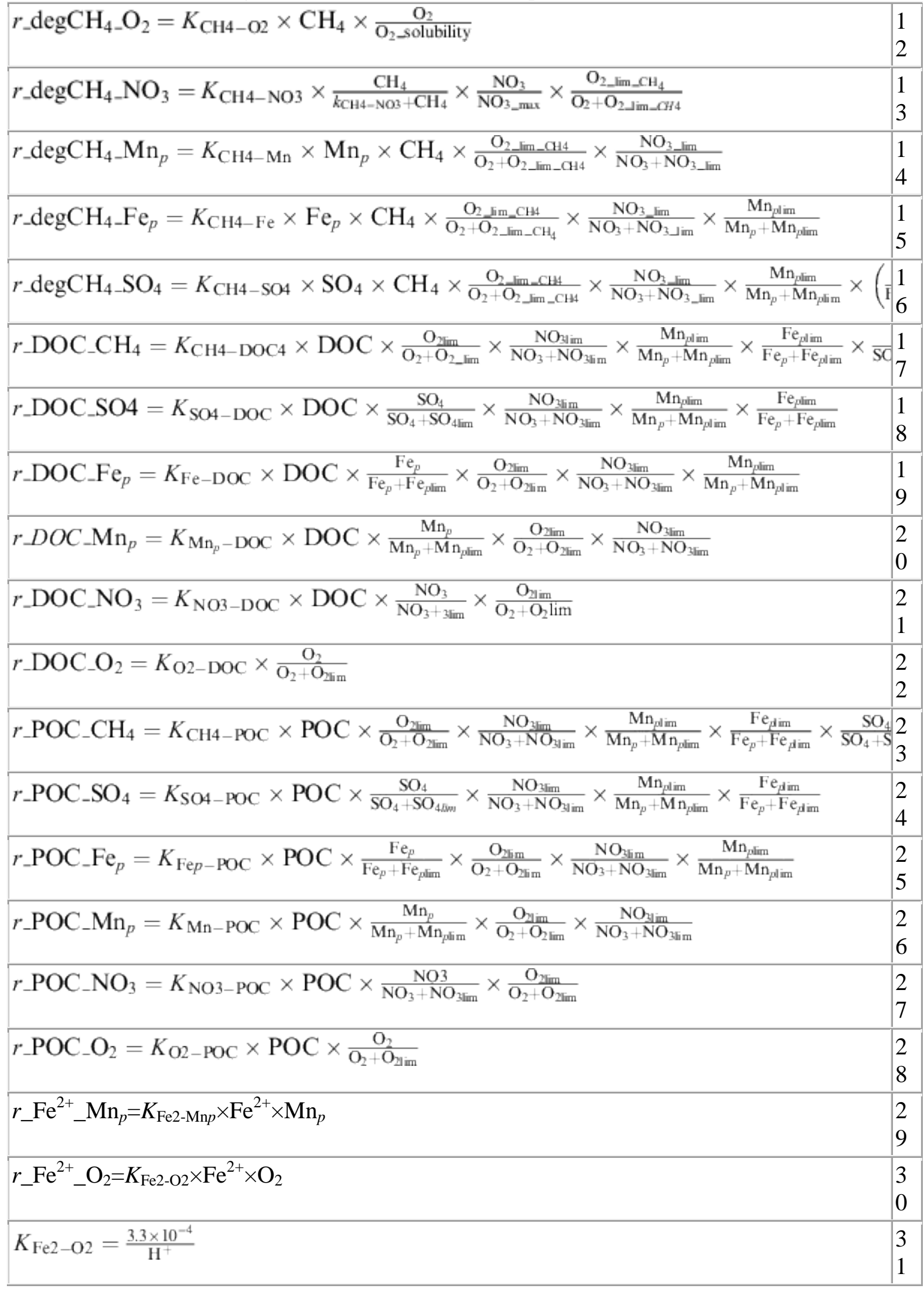




\begin{tabular}{|l|l|}
\hline$r_{-} \mathrm{Fe}^{2+}{ }_{-} \mathrm{NO}_{3}=K_{\mathrm{Fe} 2-\mathrm{NO} 3} \times \mathrm{Fe}^{2+} \times \frac{\mathrm{NO}_{3}}{\mathrm{NO}_{3}+\mathrm{NO}_{31 \mathrm{~m}}}, \mathrm{O}_{2}<0.01 \mathrm{mM}$ & 3 \\
\hline$r_{-} \mathrm{Mn}^{2+}{ }_{-} \mathrm{O}_{2}=K_{\mathrm{Mn} 2-\mathrm{O} 2} \times \mathrm{Mn}^{2+} \times \mathrm{O}_{2}$ & 3 \\
\hline$K_{\mathrm{Mn} 2-\mathrm{O} 2}=\frac{2 \times 10^{-14}}{\left(\mathrm{H}^{+}\right)^{2}}$ & 3 \\
\hline$r_{-} \mathrm{NH}_{4}^{+} \mathrm{Mn}_{p}=K_{\mathrm{NH} 4-\mathrm{Mnp}} \times \mathrm{NH}_{4}^{+} \times \mathrm{Mn}_{p}$ & 3 \\
\hline$r_{-} \mathrm{NH}_{4}^{+}{ }_{-} \mathrm{O}_{2}=K_{\mathrm{NH} 4-\mathrm{O} 2} \times \frac{\mathrm{NH}_{4}^{+}}{k_{\mathrm{NH}_{4}+\mathrm{NH}_{4}^{+}}} \times \frac{\mathrm{O}_{2}}{k_{02}+\mathrm{O}_{2}}$ & 5 \\
\hline$r_{-} \mathrm{H}_{2} \mathrm{~S}_{-} \mathrm{O}_{2}=K_{\mathrm{H} 2 \mathrm{~S}-\mathrm{O} 2} \times \sum \mathrm{S} \times \mathrm{O}_{2}$ & 3 \\
\hline
\end{tabular}

Where $K_{i}$ - Kinetic parameter, $\mathrm{O}_{2}$ - oxygen concentration $\left(\mathrm{M} \mathrm{L}^{-3}\right), \mathrm{CH}_{4}-$ methane concentration $\left(\mathrm{M} \mathrm{L}^{-3}\right), \mathrm{Mn}_{p}-$ particulate manganese concentration $\left(\mathrm{M} \mathrm{L}^{-3}\right), \mathrm{Fe}_{p}$ - particulate iron concentration $\left(\mathrm{M} \mathrm{L}^{-3}\right), \mathrm{NO}_{3}$ - nitrate concentration $\left(\mathrm{M} \mathrm{L}^{-3}\right), \mathrm{SO}_{4}$ - sulphate concentration $\left(\mathrm{M} \mathrm{L}^{-3}\right)$, DOC - dissolved organic carbon concentration (M $\left.\mathrm{L}^{-3}\right), \mathrm{POC}$ - particulate organic carbon concentration $\left(\mathrm{M} \mathrm{L}^{-3}\right), \mathrm{H}^{+}$- hydrogen ion concentration $\left(\mathrm{M} \mathrm{L}^{-3}\right), \Sigma \mathrm{S}-$ total dissolved sulfide concentration $\left(\mathrm{M} \mathrm{L}^{-3}\right), \mathrm{Fe}^{2+}$ - dissolved iron concentration $\left(\mathrm{M} \mathrm{L}^{-3}\right), \mathrm{Mn}^{2+}$ - dissolved

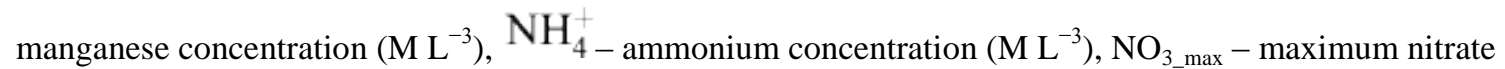
concentration in the water column $\left(\mathrm{M} \mathrm{L}^{-3}\right), \mathrm{O}_{2 \_ \text {lim_CH4 }}-$ oxygen limiting concentration for aerobic methane oxidation $\left(\mathrm{M} \mathrm{L}^{-3}\right), \mathrm{O}_{2 \lim }$ - half-saturation coefficient or oxygen limiting concentration for organic matter degradation $\left(\mathrm{M} \mathrm{L}^{-3}\right), \mathrm{SO}_{4 l i m}$ - half-saturation coefficient or sulphate limiting concentration $\left(\mathrm{M} \mathrm{L}^{-3}\right), \mathrm{NO}_{3 \_ \text {lim }}-$ half-saturation coefficient or nitrate limiting concentration $\left(\mathrm{M} \mathrm{L}^{-3}\right), \mathrm{Mn}_{p l i m}$ - half-saturation coefficient or particulate manganese limiting concentration $\left(\mathrm{M} \mathrm{L}^{-3}\right), \mathrm{Fe}_{p \mathrm{lim}}$ - half-saturation coefficient or particulate manganese limiting concentration $\left(\mathrm{M} \mathrm{L}^{-3}\right), k_{\mathrm{NH} 4}-$ ammonium half-saturation coefficient for nitrification $\left(\mathrm{M} \mathrm{L}^{-3}\right)$, $k_{\mathrm{O} 2}-$ oxygen half-saturation coefficient for nitrification $\left(\mathrm{M} \mathrm{L}^{-3}\right)$.

In contrast to the primary and secondary redox reactions described in Table 2 for which rates are shown in Table 3, the organic C export rate (Reaction (1)) is derived from total organic $\mathrm{C}$ measurements in sediment traps collected at $23 \mathrm{~m}$ depth from May 2006 to May 2007 (Fig. 1). The organic $\mathrm{C}$ export reaction generates particulate and dissolved organic $\mathrm{C}$. The fraction of dissolved organic $\mathrm{C}$ is arbitrarily set at $10 \%$ of the particulate organic $\mathrm{C}$ produced in the epilimnion (Reichert et al., 2001). 


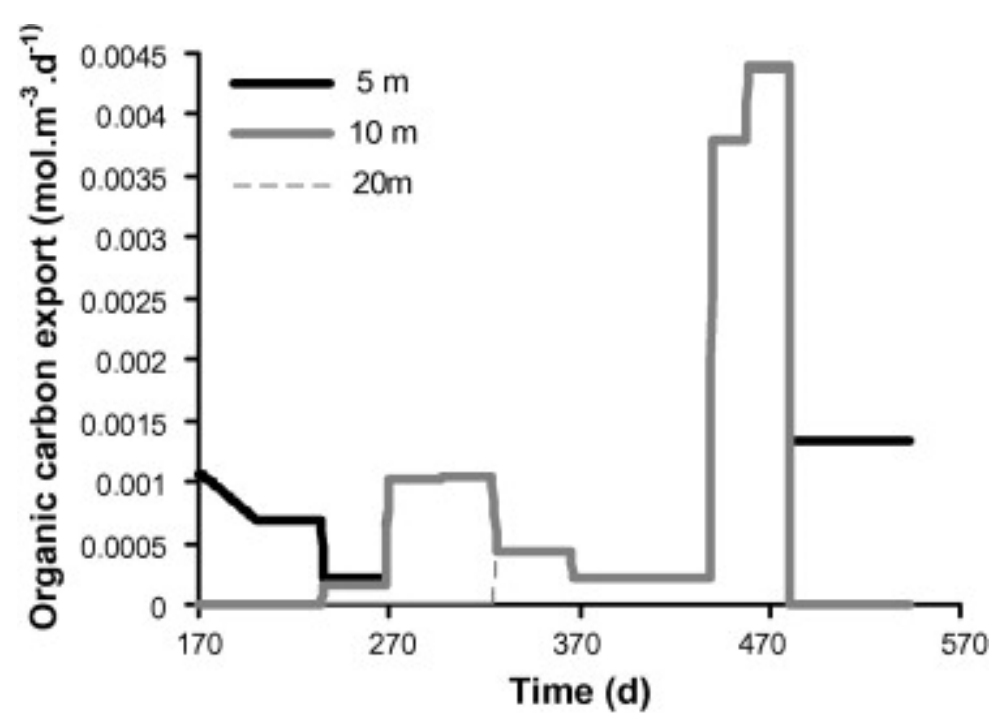

Fig. 1. : Organic C export reaction used in the model.

\subsubsection{Acid-base reactions}

In contrast to redox reactions, acid-base reactions reach equilibrium almost instantaneously. Although the AQUASIM code can solve algebraic equations, classic calculation of $\mathrm{pH}$ in a dynamic system frequently leads to numerical problems. In order to calculate water column $\mathrm{pH}$, the following equations were implemented:(38)

$$
\begin{aligned}
\mathrm{R}_{\mathrm{B}}= & \mathrm{R}_{\mathrm{B}}^{0}+\left[\mathrm{NH}_{4}^{+}\right]-\left[\mathrm{NH}_{4}^{+}\right]_{0}+2\left[\mathrm{Fe}^{2+}\right]-2\left[\mathrm{Fe}^{2+}\right]_{0}+2\left[\mathrm{Mn}^{2+}\right] \\
& -2\left[\mathrm{Mn}^{2+}\right]_{0}-\left[\mathrm{NO}_{3}^{-}\right]+\left[\mathrm{NO}_{3}^{-}\right]_{0}-2 \times\left[\mathrm{SO}_{4}^{2-}\right]+2 \times\left[\mathrm{SO}_{4}^{2-}\right]_{0}
\end{aligned}
$$

where the alkaline reserve, $\mathrm{R}_{\mathrm{B}}$, stands for the sum of nonreactive species $\left(\mathrm{Na}^{+}, \mathrm{K}^{+}, \mathrm{Ca}^{2+}\right.$, $\left.\mathrm{Mg}^{2+}, \mathrm{Cl}^{-}\right)$as follows:(39) $\mathrm{R}_{\mathrm{B}}=\left[\mathrm{Na}^{+}\right]+\left[\mathrm{K}^{+}\right]+2\left[\mathrm{Ca}^{2+}\right]+2\left[\mathrm{Mg}^{2+}\right]-\left[\mathrm{Cl}^{-}\right]$and the sum of species which are consumed or produced by the redox reactions: inactive acids or bases $\left(\mathrm{NO}_{3}^{-}, \mathrm{SO}_{4}^{2-}\right)$ or species which are assumed as inactive in the conditions of the lake $\left(\mathrm{NH}_{4}^{+}, \mathrm{Mn}^{2+}, \mathrm{Fe}^{2+}\right)$ (Michard, 1989). In fact, the latter species are only found in the reduced and relatively acid layers where the $\mathrm{pH}(<7.5)$ is significantly lower than the $\mathrm{p} K_{a}$ of these acids. $\mathrm{R}_{\mathrm{B}}^{0}$ is the algebraic sum of the charges of unproduced and/or unconsumed charged species. The $\mathrm{R}_{\mathrm{B} \text { only }}^{0}$ changes with the difference between river inflows and outflows. The subscript " 0 " indicates the concentration of each chemical species at the initial time.

With $\mathrm{R}_{\mathrm{B}}$ and DIC values, proton activity is calculated by Eq. (40):(40)R $\mathrm{R}_{\mathrm{B}} / \mathrm{DIC}=\left(1+2 K_{a 2} / \mathrm{H}^{+}\right) /\left(1+\mathrm{H}^{+} / K_{a 1}+K_{a 2} / \mathrm{H}^{+}\right)$where $K_{a 1}$ and $K_{a 2}$ are the equilibrium constants of the chemical equilibria between $\mathrm{CO}_{2}$ and $\mathrm{HCO}_{3}^{-}$and between $\mathrm{HCO}_{3}^{-}$and $\mathrm{CO}_{3}^{2-}$, respectively. It should be stressed that Eq. (40) is valid for a water column pH lower than 9.5, which is consistent with the maximum $\mathrm{pH}$ values reported in Lake Pavin ( [Michard et al., 1994] and [Assayag et al., 2008] ). 


\subsubsection{Initial conditions}

Initial conditions for concentrations of dissolved species in the water column are those observed on June 17, 2006, except for dissolved and particulate Fe and Mn, POC, DIC and pH. Particulate Fe, Mn and DIC concentration profiles were measured in September 1993 (Viollier, 1995). Dissolved Fe, Mn and pH were determined in 1993 (Viollier, 1995). The initial POC profile was determined in June 1973 (Devaux et al., 1983) but it was not casesensitive.

\subsubsection{Modelling approach}

Model calculations were performed starting from the 17th of June 2006 and simulations were carried out over 1 year. In model calculations half-saturation coefficients in Monod-type expressions and the maximum rates of the processes described in Table 3 were based on values reported in the literature (e.g. [Hunter et al., 1998] , [Smith and Jaffé, 1998], [Lidstrom and Somers, 1984] , [Smith et al., 1991] and [Omlin et al., 2001] ). The kinetic parameters of the biogeochemical processes (see "a" - fitted parameters in Table 4) were iteratively changed by a trial-and-error approach until simulations led to visual fit agreement with measurements of monthly depth profiles of $\mathrm{CH}_{4}$, dissolved $\mathrm{O}_{2}, \mathrm{NO}_{3}^{-}, \mathrm{SO}_{4}^{2-}$, and whenever available, dissolved organic $\mathrm{C}$, dissolved Fe, dissolved $\mathrm{Mn}$ and $\mathrm{NH}_{4}^{+}$. Early diagenesis of organic matter was not implemented in the model and the benthic contribution was taken into account through benthic boundary conditions. For instance, benthic flux of $\mathrm{CH}_{4}$ had to be increased by a factor of two compared with the field estimation (Table 1 and Table 4). Owing to the large uncertainty of the field derived value (possible $\mathrm{CH}_{4}$ loss, centimetre-scale gradient resolution only), this adjustment remains acceptable. Following model calibration, depth concentration profiles of particulate organic $\mathrm{C}$ predicted by the model were compared with data obtained from field campaigns in 1992 (Carrias, 1996 and [Carrias et al., 1998] ).

Table 4. Lake Pavin biogeochemical model: kinetic constants and adjusted parameters.

\begin{tabular}{|c|c|}
\hline Parameter & Value \\
\hline$K_{\mathrm{CH} 4 \_\mathrm{Fe}}$ & $0.005 \mathrm{~mol}^{-1} \mathrm{~m}^{3} \mathrm{day}^{-1} \underline{\mathrm{a}}$ \\
\hline $\mathrm{O}_{2 \lim }$ & $0.02 \mathrm{~mol} \mathrm{~m}^{-3}$ \\
\hline $\mathrm{O}_{2 \mathrm{lim} \_\mathrm{CH} 4}$ & $0.02 \mathrm{~mol} \mathrm{~m}^{-3}$ \\
\hline $\mathrm{NO}_{3 \mathrm{lim}}$ & $0.005 \mathrm{~mol} \mathrm{~m}^{-3}$ \\
\hline $\mathrm{Mn}_{\text {plim }}$ & $0.0032 \mathrm{~mol} \mathrm{~m}^{-3}$ \\
\hline $\mathrm{NO}_{3 \max }$ & $0.1 \mathrm{~mol} \mathrm{~m}^{-3}$ \\
\hline$K_{\mathrm{CH} 4 \_\mathrm{Mn}}$ & $0.05 \mathrm{~m}^{3} \mathrm{~mol}^{-1} \mathrm{day}^{-1} \underline{\mathrm{a}}$ \\
\hline$K_{\mathrm{CH} 4 \_\mathrm{SO} 4}$ & $0.0274 \mathrm{~m}^{3} \mathrm{~mol}^{-1} \mathrm{day}^{-1}$ \\
\hline $\mathrm{Fe}_{\text {plim }}$ & $0.0032 \mathrm{~mol} \mathrm{~m}^{-3}$ \\
\hline $\mathrm{SO}_{4 \lim }$ & $0.03 \mathrm{~mol} \mathrm{~m}^{-3}$ \\
\hline$K_{\mathrm{CH} 4 \_\mathrm{NO} 3}$ & $0.03 \mathrm{~mol} \mathrm{~m}^{-3} \mathrm{day}^{-1} \underline{\mathrm{a}}$ \\
\hline$k_{\mathrm{CH} 4 \_\mathrm{NO} 3}$ & $0.0006 \mathrm{~mol} \mathrm{~m}^{-3}$ \\
\hline$K_{\mathrm{CH} 4 \_\mathrm{O} 2}$ & 0.14 day $^{-1}$ \\
\hline
\end{tabular}




\begin{tabular}{|l|l|}
\hline Parameter & Value \\
\hline$K_{\mathrm{CH} 4 \_\mathrm{DOC}}$ & $0.00014 \mathrm{day}^{-1} \underline{\mathrm{a}}$ \\
\hline$K_{\mathrm{CH} 4 \_\mathrm{POC}}$ & $0.00014 \mathrm{day}^{-1}$ \\
\hline$K_{\mathrm{SO} 4 \_\mathrm{POC}}$ & $0.00047 \mathrm{day}^{-1}$ \\
\hline$K_{\mathrm{SO} 4 \_\mathrm{DOC}}$ & $0.0047 \mathrm{day}^{-1} \underline{\mathrm{b}}$ \\
\hline$K_{\mathrm{Fe} \_\mathrm{POC}}$ & $0.000014 \mathrm{day}^{-1}$ \\
\hline $\mathrm{K}_{\mathrm{Fe} \_\mathrm{DOC}}$ & $0.00014 \mathrm{day}^{-1} \underline{\mathrm{b}}$ \\
\hline$K_{\mathrm{Mn} \_\mathrm{POC}}$ & $0.000027 \mathrm{day}^{-1}$ \\
\hline$K_{\mathrm{Mn} \_\mathrm{DOC}}$ & $0.00027 \mathrm{day}^{-1} \underline{\mathrm{b}}$ \\
\hline$K_{\mathrm{NO} 3 \_\mathrm{POC}}$ & $0.01 \mathrm{day}^{-1}$ \\
\hline$K_{\mathrm{NO} 3 \_\mathrm{DOC}}$ & $0.01 \mathrm{day}^{-1} \underline{\mathrm{a}}$ \\
\hline$K_{\mathrm{O} 2 \_\mathrm{DOC}}$ & $0.01 \mathrm{day}^{-1} \underline{\mathrm{a}}$ \\
\hline$K_{\mathrm{O} 2 \_\mathrm{POC}}$ & $0.04 \mathrm{day}^{-1} \underline{\mathrm{a}}$ \\
\hline$K_{\mathrm{Fe} 2 \_\mathrm{Mnp}}$ & $0.0274 \mathrm{~m}^{3} \mathrm{~mol}^{-1} \mathrm{~d}^{-1}$ \\
\hline$K_{\mathrm{Fe} 2 \_\mathrm{NO} 3}$ & $0.01 \mathrm{~m}^{3} \mathrm{~mol}^{-1} \mathrm{day}^{-1} \underline{\mathrm{a}}$ \\
\hline$K_{\mathrm{NH} 4 \_\mathrm{Mnp}}$ & $0.001 \mathrm{~m}^{3} \mathrm{day}^{-1}$ \\
\hline$K_{\mathrm{NH} 4 \_\mathrm{O} 2}$ & $0.001 \mathrm{~mol} \mathrm{~m}^{-3} \mathrm{day}^{-1} \underline{\mathrm{a}}$ \\
\hline$k_{\mathrm{NH} 4}$ & $0.036 \mathrm{~mol} \mathrm{~m}^{-3}$ \\
\hline$K_{\mathrm{O} 2}$ & $0.025 \mathrm{~mol} \mathrm{~m}^{-3}$ \\
\hline$K_{\mathrm{H} 2 \mathrm{~S} \_\mathrm{O} 2}$ & $0.438 \mathrm{~mol}^{-1} \mathrm{~m}^{3} \mathrm{day}^{-1}$ \\
\hline$F_{-\mathrm{CH} 4 \_92 \mathrm{~m}}$ & $5.2 \times 10^{-3} \mathrm{~mol} \mathrm{~m}^{-2} \mathrm{day}^{-1} \underline{\mathrm{a}}$ \\
\hline$K_{1}$ & \\
\hline
\end{tabular}

Kinetic parameters values from (1) Hunter et al. (1998), (2) [Lidstrom and Somers, 1984] and [Smith and Jaffé, 1998]; (4) Raghoebarsing (2006), (5) Omlin et al. (2001).

${ }^{\mathrm{a}}$ Fitted parameter.

${ }^{\mathrm{b}}$ In the model, DOC is assumed highly biodegradable. Therefore, kinetic parameters of DOC degradation were initially assumed to be tenfold higher than those of POC biodegradation. Some of these parameters were then modified in order to achieve a good fit of the data and the model predictions.

\subsubsection{Sensitivity analysis}

A sensitivity analysis was performed in order to determine the model sensitivity to imperfect knowledge of (1) some kinetic parameters related to the $\mathrm{CH}_{4}$ pathways $\left(K_{\mathrm{CH} 4 \_F e}, K_{\mathrm{CH} 4 \_M n}\right.$, $K_{\mathrm{CH} 4 \_\mathrm{DOC}}, K_{\mathrm{CH} 4 \_\mathrm{NO} 3}, k_{\mathrm{CH} 4 \_\mathrm{NO} 3}$ and $\mathrm{NO}_{3 \mathrm{lim}}$ ) and (2) vertical mixing (eddy diffusion coefficient $K_{z}$ ). The relative uncertainties of the kinetic parameters were assumed to be $50 \%$ and the eddy diffusion coefficients were doubled. In the first step, these parameters were analyzed separately. In the second step, the impact of uncertainties of all the kinetic parameters of the $\mathrm{CH}_{4}$ degradation pathways was tested (half-saturation coefficients, maximum rates and inhibition factors, see Table 3).

\section{Results}




\subsection{Limnology}

From a geochemical point of view, the upper layer of the mixolimnion is oxygenated with a $\mathrm{pH}$ that can vary from 8 to 9 above the thermocline (Michard et al., 1994). Temperature at the lake surface varied from $3.4{ }^{\circ} \mathrm{C}$ in February 2007 (data not shown) to $22{ }^{\circ} \mathrm{C}$ in July 2006 (Fig. 2). During the winter 2006-2007, the mixolimnion was vertically thoroughly mixed from January to February 2007. Lower layers in the mixolimnion (from $20 \mathrm{~m}$ to $55 \mathrm{~m}$ ) have a constant temperature of $4{ }^{\circ} \mathrm{C}$ all year long. From $60 \mathrm{~m}$ depth, an increase in temperature is observed due to the geothermal flux and turbulent heat exchange restriction between the monimo-mesolimnion and the mixolimnion (temperature $=5.06{ }^{\circ} \mathrm{C}$ at the bottom of the lake). This limitation is illustrated in Fig. 3 which shows conductivity profiles in Lake Pavin from June 2006 to June 2007. As expected, a permanent zone of strong chemical gradient is observed from approximately 60 to $70 \mathrm{~m}$ depth. Fairly weak eddy diffusion coefficients in this layer are essentially related to the corresponding strong density gradient.

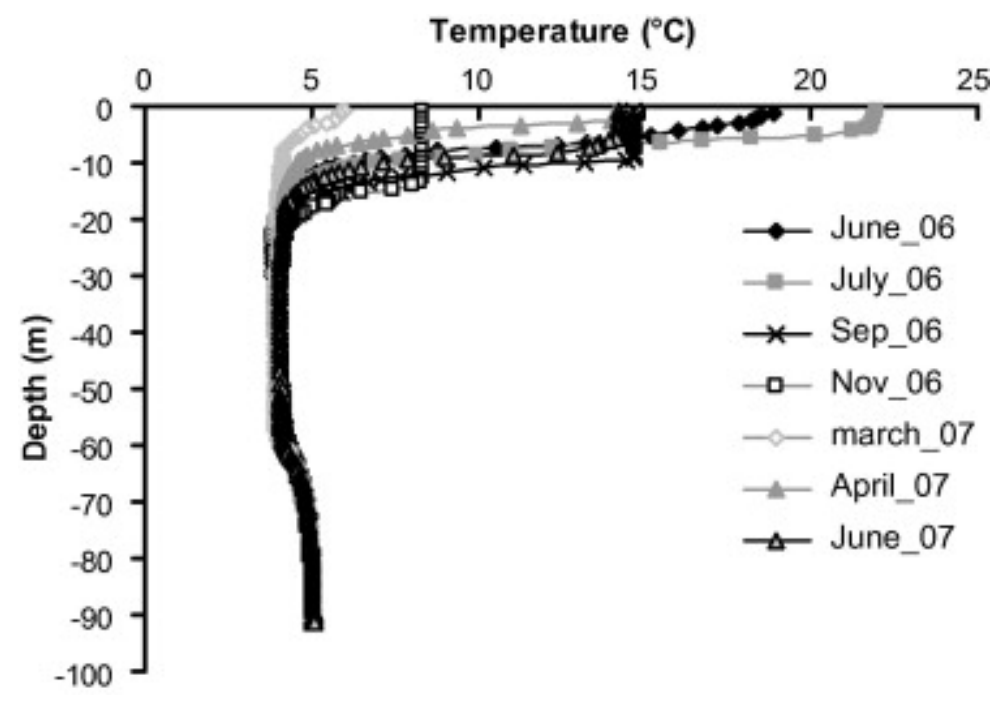

Fig. 2. : Measured temperature profiles in the water column.

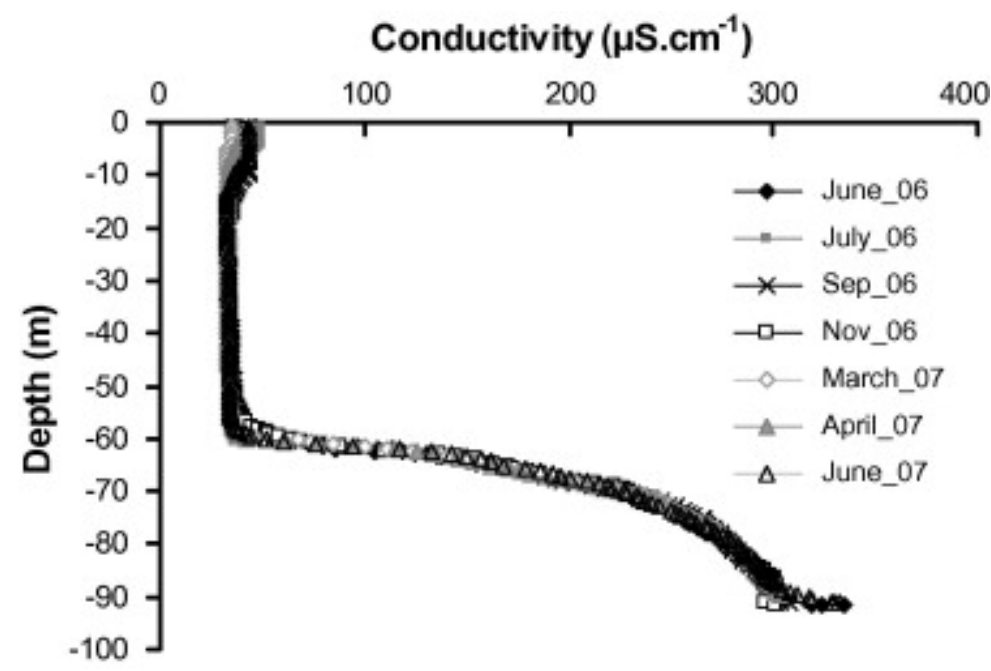

Fig. 3. : Measured conductivity profiles in the water column. 
Fig. 4a presents $\mathrm{CH}_{4}$ concentration profiles from June 2006 to June 2007. Methane concentrations increase sharply at approximately $55 \mathrm{~m}$ depth to reach $4 \times 10^{-3} \mathrm{~mol} \mathrm{~L}^{-1}$ at 92 $\mathrm{m}$ depth. Differences in $\mathrm{CH}_{4}$ concentrations for the deepest layers are observed in June 2007 but globally from 30 years of observations, the monimolimnion is considered to have reached interannual steady state ( [Viollier et al., 1997] and [Michard et al., 2003] ). However, significant increase of $\mathrm{CH}_{4}$ is also observed in the epilimnion (Fig. 4b). Fig. 5 a and b show the overlapping concentration profiles of, $\mathrm{CH}_{4}, \mathrm{O}_{2}, \mathrm{NO}_{3}^{-}$and $\mathrm{SO}_{4}^{2-}$ for June 2006 at the boundary between the mixolimnion and the mesolimnion. Also overlapping concentration profiles of particulate Fe and Mn measured in September 1993 are given in Fig. 6 for the same layers. These results underline the possibility that $\mathrm{CH}_{4}$ can react aerobically or anaerobically with multiple substrates in Lake Pavin. 

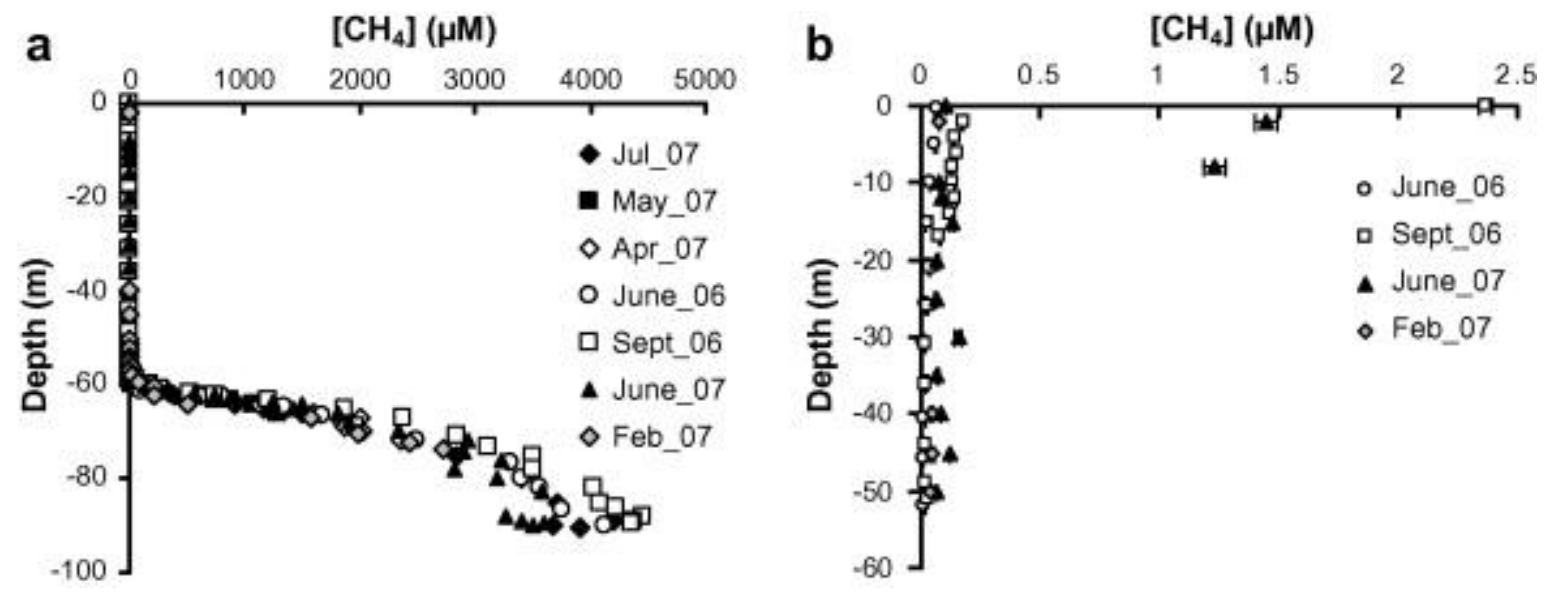

Fig. 4. /Methane concentration profiles for June 2006, September 2006, February 2007, April 2007, May 2007, June 2007 and July 2007. No $\mathrm{CH}_{4}$ concentration profiles are presented in Fig. 4b for April, May and July 2007 because no data are available for depths below $50 \mathrm{~m}$.
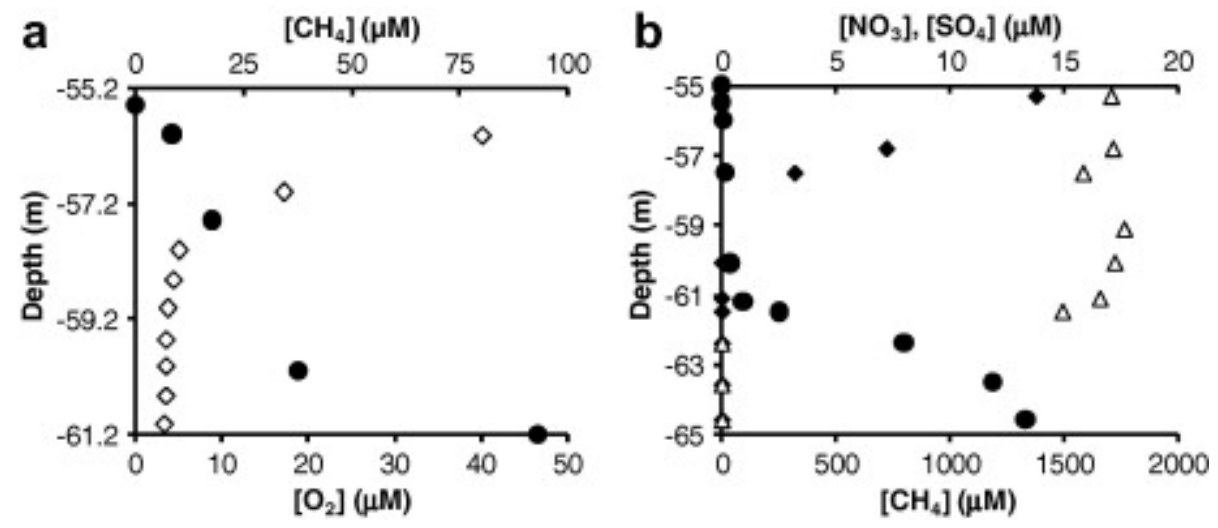

Fig. 5. : Methane and $\mathrm{O}_{2}$ depth profiles (a), $\mathrm{CH}_{4}, \mathrm{NO}_{3}^{-}$and $\mathrm{SO}_{4}^{2-}$ concentration profiles (b) in June $2006\left(\diamond-\mathrm{O}_{2}, \bullet-\mathrm{CH}_{4}, \Delta-\mathrm{SO}_{4}^{2-},-\mathrm{NO}_{3}^{-}\right)$. 


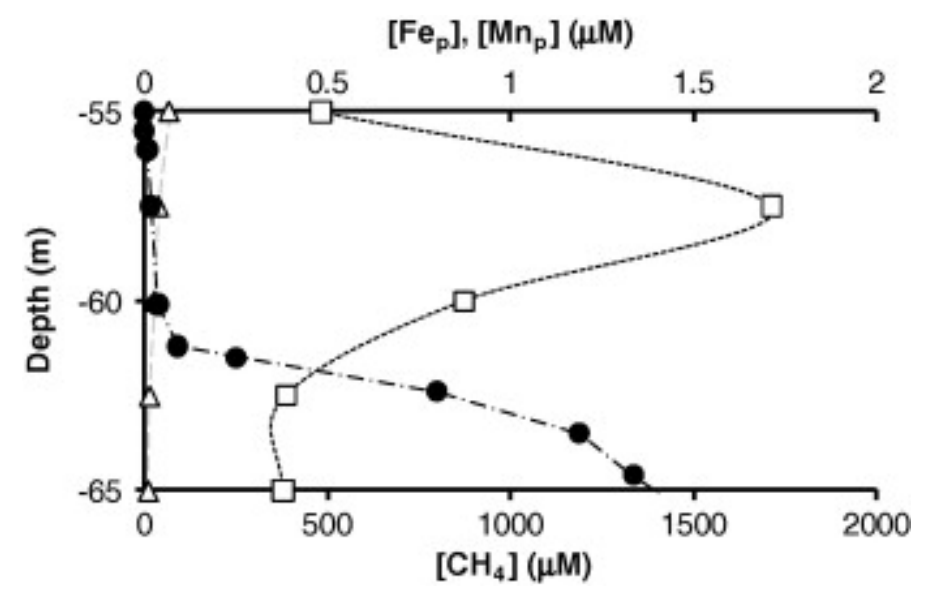

Fig. 6. :Depth profiles of $\mathrm{CH}_{4}$, particulate $\mathrm{Fe}\left(\mathrm{Fe}_{\mathrm{p}}\right)$ and $\mathrm{Mn}\left(\mathrm{Mn}_{\mathrm{p}}\right)$ in September $1993(\square-$ $\left.\mathrm{Fe}_{\mathrm{p}}, \bullet-\mathrm{CH}_{4}, \Delta-\mathrm{Mn}_{\mathrm{p}}\right)$.

\subsection{Methane in sediment}

The $\mathrm{CH}_{4}$ concentration profile in the sediment collected at $40 \mathrm{~m}$ depth is presented in Fig. 7 . From this profile and the one at $92 \mathrm{~m}$ depth (data not shown), $\mathrm{CH}_{4}$ flux from the sediment was calculated by applying Fick's first law of diffusion. The measured dissolved $\mathrm{CH}_{4}$ concentration in the water at $40 \mathrm{~m}$ depth was about $0.08 \times 10^{-6} \mathrm{~mol} \mathrm{~L}^{-1}$. Using a porosity value of 0.98 (Viollier, 1995), one can calculate the sediment diffusion coefficient of $\mathrm{CH}_{4}(8.2$ $\times 10^{-5} \mathrm{~m}^{2}$ day $^{-1}$ ) at $4{ }^{\circ} \mathrm{C}$ (Boudreau, 1997). Resulting benthic fluxes from the sediments at 40 $\mathrm{m}$ and $92 \mathrm{~m}$ depths were $5.8 \times 10^{-4}$ and $2.6 \times 10^{-3} \mathrm{~mol} \mathrm{~m}^{-2}$ day $^{-1}$ (Table 1), respectively.

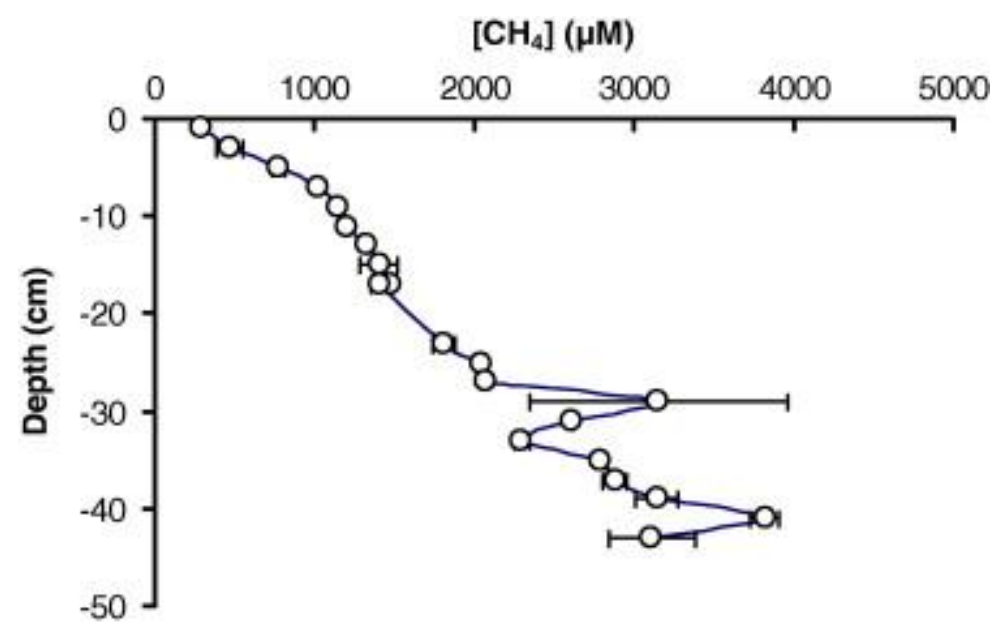

Fig. 7. : Methane concentration profile in sediment pore water sampled at $40 \mathrm{~m}$ depth.

\subsection{Methane oxidation in the water column}

Measured rates of aerobic $\mathrm{CH}_{4}$ oxidation varied between $6.2 \times 10^{-9}$ and $4.6 \times 10^{-8} \mathrm{~mol} \mathrm{~L}^{-1}$ day $^{-1}$ for $\mathrm{CH}_{4}$ concentrations ranging from $0.06 \times 10^{-6}$ to $0.35 \times 10^{-6} \mathrm{~mol} \mathrm{~L}^{-1}$. The rate of 
$\mathrm{CH}_{4}$ oxidation displayed first-order kinetics with respect to $\mathrm{CH}_{4}$ concentration $\left(r^{2}=0.92\right.$; $\left.r_{\mathrm{CH} 4-\mathrm{O} 2}\left(\mathrm{mmol} \mathrm{L}^{-1} \mathrm{day}^{-1}\right)=0.14 \times\left[\mathrm{CH}_{4}\right]\right)$ with an excess of $\mathrm{O}_{2}($ no limiting effect $)$.

Since $\mathrm{O}_{2}$ is a key factor in the aerobic $\mathrm{CH}_{4}$ oxidation, its influence on the kinetics of this reaction is taken into account by considering an additional term $\mathrm{O}_{2} / \mathrm{O}_{2}$ solubility (Eq. (12), Table 3 ). This modified kinetics was then implemented in the model (Table 3 and Table 4).

Moreover, at 60 and $62 \mathrm{~m}$ depth, a net $\mathrm{CH}_{4}$ loss of $0.4 \times 10^{-6} \mathrm{~mol} \mathrm{~L}^{-1}$ day ${ }^{-1}$ was measured for $285 \times 10^{-6}$ and $785 \times 10^{-6} \mathrm{~mol} \mathrm{~L}^{-1}$ initial $\mathrm{CH}_{4}$ concentrations, respectively. These results suggest that anaerobic $\mathrm{CH}_{4}$ oxidation may occur in the water column of Lake Pavin.

\subsection{Model results}

\subsubsection{Species concentration in the water column}

Measured and simulated concentration profiles of $\mathrm{CH}_{4}, \mathrm{NO}_{3}^{-}, \mathrm{SO}_{4}^{2-}$ and $\mathrm{O}_{2}$ in June 2007 are compared in Fig. 8a. General trends are qualitatively reproduced by the simulation. However, higher concentrations of $\mathrm{NO}_{3}^{-}$and $\mathrm{SO}_{4}^{2-}$ were encountered between 40 and $60 \mathrm{~m}$ depth compared with the values expected from the model. The effect of the sublacustrine input within this depth range, by the addition of $\mathrm{NO}_{3}^{-}$and $\mathrm{SO}_{4}^{2-}$ into the water column, may explain these discrepancies.
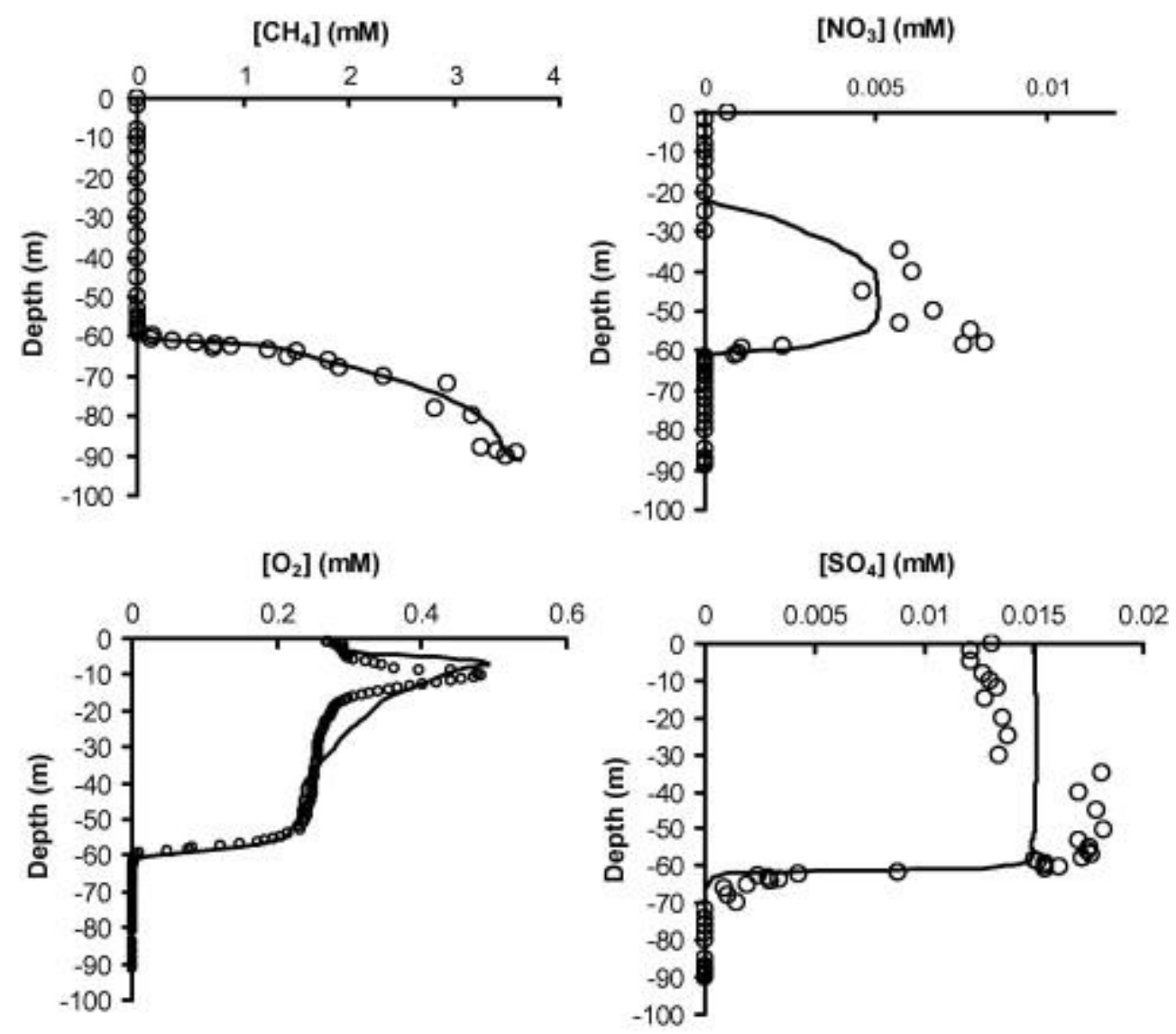

Fig. 8a. : Measured and modelled concentration profiles of $\mathrm{CH}_{4}, \mathrm{NO}_{3}^{-}, \mathrm{O}_{2}$ and $\mathrm{SO}_{4}^{2-}$ in June 2007 (markers represent measurements and lines simulated concentrations). 
In Fig. 8b, POC concentration profiles in the mixolimnion calculated for August, October, November 2006 and April 2007 were compared to data measured in 1992 (Carrias, 1996 and [Carrias et al., 1998] ). It can be seen that POC model predictions are of the same order of magnitude as the data measured at 1, 5, 10, 15 and $40 \mathrm{~m}$ depths in the field campaigns of 1992.

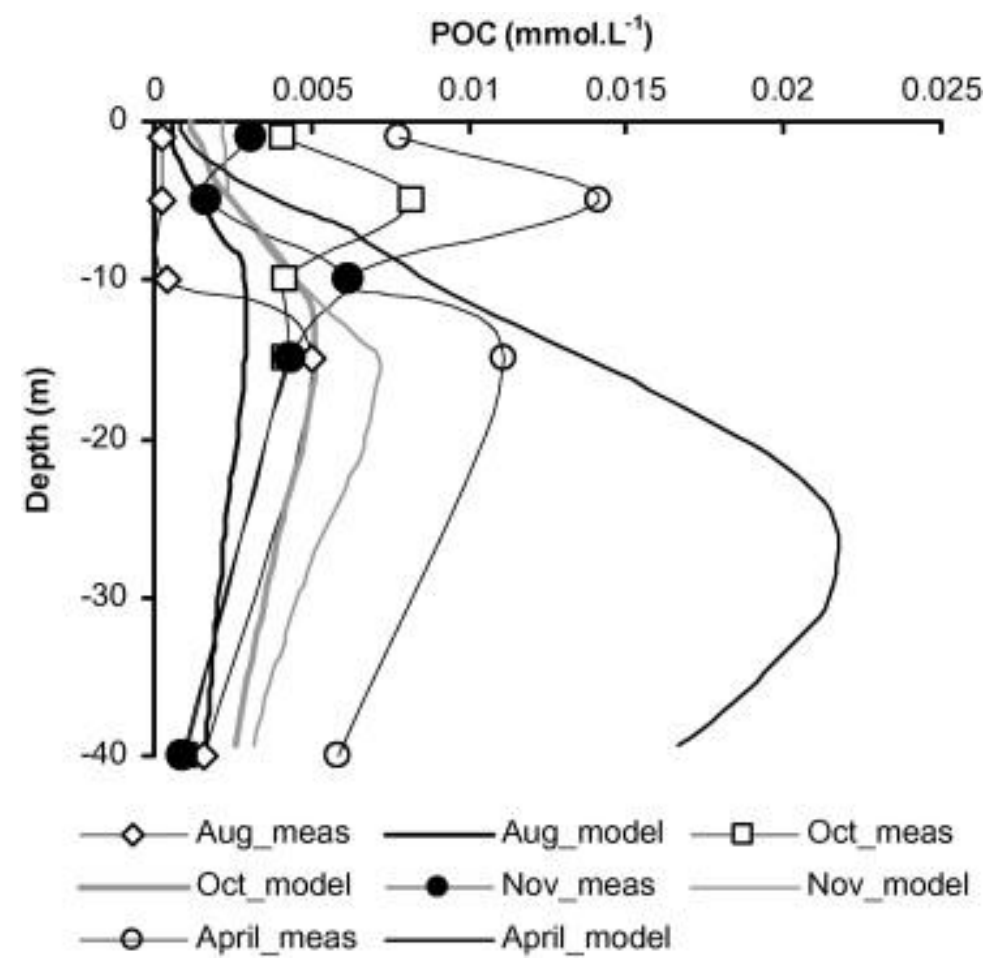

Fig. 8b. : Simulated POC vs. POC measured in 1992.

\subsubsection{Methane oxidation in the water column}

Fig. 9 shows calculated rates of $\mathrm{CH}_{4}$ oxidation in February and in June 2007. These two examples were chosen in order to evaluate the effect of winter mixing in $\mathrm{CH}_{4}$ consumption and production pathways. An overlap between aerobic and anaerobic pathways is observed. Additionally, a seasonal difference between aerobic and anaerobic rates can be detected. In June 2007, aerobic $\mathrm{CH}_{4}$ oxidation occurs in a narrow zone at the boundary of oxic-anoxic layers. In contrast, in February, aerobic $\mathrm{CH}_{4}$ oxidation occurs in the upper layers of the mixolimnion. Winter mixing led to higher flux of $\mathrm{CH}_{4}$ towards the upper layers of the mixolimnion and consequently to higher $\mathrm{CH}_{4}$ concentrations (Fig. 10). This allows aerobic $\mathrm{CH}_{4}$ oxidation to occur at higher rates compared to those of the stratified period. 

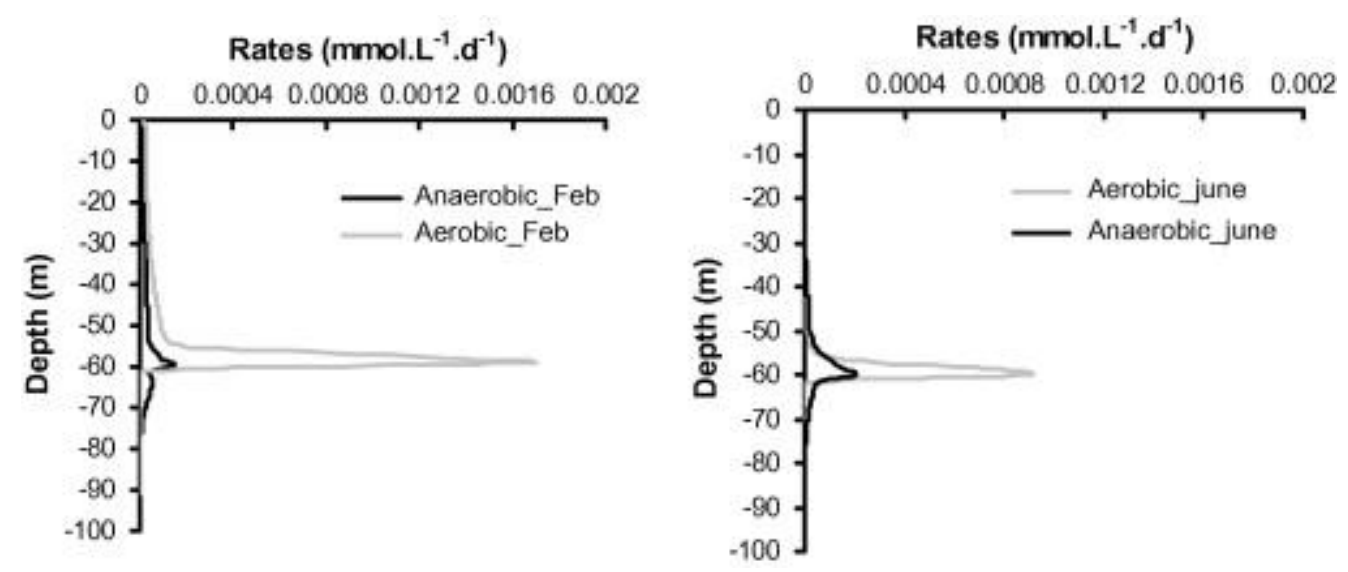

Fig. 9. : Modelled rates of aerobic and anaerobic $\mathrm{CH}_{4}$ oxidation in February and June 2007.
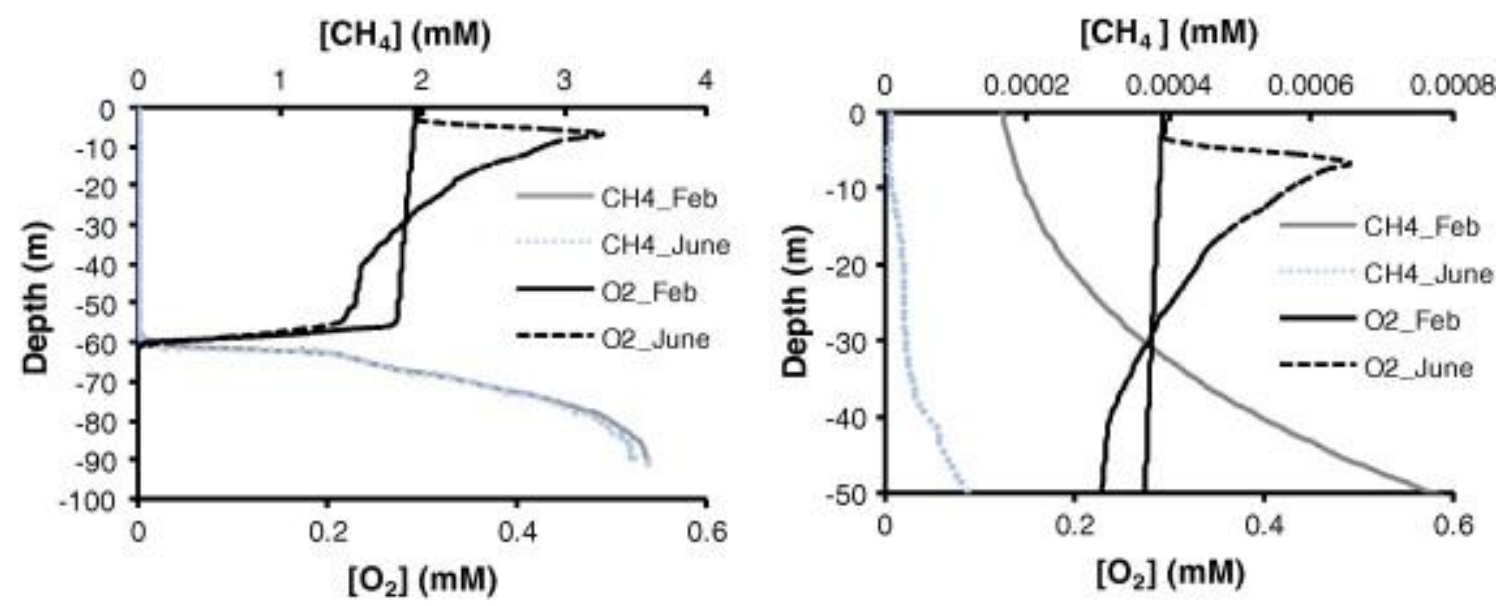

Fig. 10. :Modelled $\mathrm{CH}_{4}$ and $\mathrm{O}_{2}$ concentration profiles in February and June 2007 (a), zoomed concentration profiles of $\mathrm{CH}_{4}$ and $\mathrm{O}_{2}(\mathrm{~b})$.

Vertical distribution of the anaerobic $\mathrm{CH}_{4}$ oxidation pathways is shown in Fig. 11. Rates of Mn dependent oxidation of $\mathrm{CH}_{4}$ are not presented because they are extremely low compared with those of the other electron acceptors. This is mainly due to the low concentration of $\mathrm{Mn}$ oxides in the water column. The highest rate of AOM observed at a depth of approximately 60 m corresponds to $\mathrm{NO}_{3}^{-}$reduction. This metabolism explains the overlap between aerobic and anaerobic $\mathrm{CH}_{4}$ oxidation pathways shown in Fig. 9. Anaerobic $\mathrm{CH}_{4}$ oxidation by $\mathrm{Fe}$ and $\mathrm{SO}_{4}^{2-}$ also contribute to anaerobic $\mathrm{CH}_{4}$ consumption in the water column. 

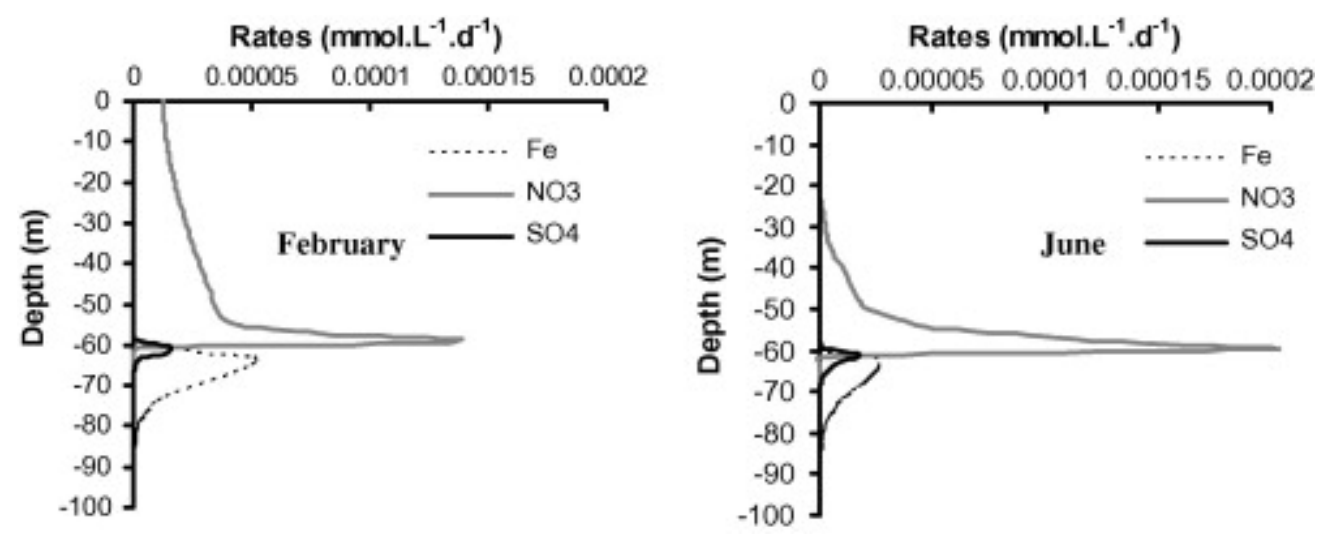

Fig. 11. : Modelled rates of $\mathrm{CH}_{4}$ oxidation coupled to the reduction of $\mathrm{Fe}, \mathrm{NO}_{3}^{-}$and $\mathrm{SO}_{4}^{2-}$.

\subsubsection{Sources and sinks of methane in Lake Pavin}

In order to have a broader picture of methane sinks and sources in Lake Pavin, depthintegrated rates of $\mathrm{CH}_{4}$ production and consumption for the entire water column in February and in June 2007 are presented in Table 5 Accordingly, a net consumption of $\mathrm{CH}_{4}$ in the water column is reported. Aerobic $\mathrm{CH}_{4}$ oxidation is the most significant $\mathrm{CH}_{4}$ consumption pathway, contributing to $74 \%$ and $67 \%$ of the total $\mathrm{CH}_{4}$ degradation in the water column in February and in June 2007, respectively, followed by denitrification (21\% and 27\% in February and in June, respectively) and Fe reduction (4\% and 5\% in February and June, respectively). Model calculations estimated a net flux of $\mathrm{CH}_{4}$ to the atmosphere in February $\left(0.2 \times 10^{-3} \mathrm{~mol} \mathrm{~m}^{-2}\right.$ day $\left.^{-1}\right)$ and a negligible flux to the lake in June $\left(3 \times 10^{-6} \mathrm{~mol} \mathrm{~m}^{-2}\right.$ day $\left.^{-1}\right)$. Methane production in the water column is also proposed by the calculations (Table 5).

Table 5. Depth integrated sources (positive values) and sinks (negative values) of $\mathrm{CH}_{4}$ in February and June 2007, compared with $\mathrm{CH}_{4}$ stock in the water column.

\begin{tabular}{|l|l|l|}
\hline Process $\left(\right.$ mol day $\left.^{-1}\right)$ & February 2007 & June 2007 \\
\hline Aerobic $\mathrm{CH}_{4}$ oxidation & $-17 \times 10^{2}$ & $-6 \times 10^{2}$ \\
\hline Anaerobic $\mathrm{CH}_{4}$ oxidation & $-6 \times 10^{2}$ & $-3 \times 10^{2}$ \\
\hline $\mathrm{CH}_{4}$ production in the water column & $1 \times 10^{2}$ & $1 \times 10^{2}$ \\
\hline $\mathrm{CH}_{4}$ flux from the sediment & $8 \times 10^{2}$ & $8 \times 10^{2}$ \\
\hline $\mathrm{CH}_{4}$ water-air exchange & $-0.7 \times 10^{2}$ & $0.02 \times 10^{2}$ \\
\hline $\mathrm{CH}_{4}$ stock (mol) & $10 \times 10^{6}$ & $10 \times 10^{6}$ \\
\hline
\end{tabular}

Methanogenesis and oxidation rates are normalized to volume and depth integrated.Benthic fluxes are normalized to the sediment surface and depth integrated.Air-water fluxes are normalized to the area at the surface of the lake.Stocks are calculated from concentration profiles.Negative sign stands for sinks and positive sign for sources. 


\subsubsection{Sensitivity analysis}

Simulations showed that variability in the tested kinetic parameters did not significantly affect the modelled species profiles. Moreover, changes in the $\mathrm{CH}_{4}$ concentration profiles were observed when the eddy diffusion coefficients were doubled. Slight changes were detected in the modelled profiles of the other dissolved parameters and particulate species. The aerobic and anaerobic $\mathrm{CH}_{4}$ oxidation rates were also sensitive to vertical mixing variability.

A sensitivity analysis was performed to evaluate the effect of the combination of all kinetic parameters of the $\mathrm{CH}_{4}$ oxidation pathways on the rates of $\mathrm{CH}_{4}$ oxidation. The possibility of compensation of an effect on the results caused by a change of one parameter in the set by an appropriate change of the other parameter may occur.

Fig. 12 shows the sensitivity of the $\mathrm{CH}_{4}$ consumption rates in June 2007 to those kinetic parameters. Iron and $\mathrm{SO}_{4}^{2-}$ dependent $\mathrm{AOM}$ seem to be highly sensitive to the combination of the parameters involved in the $\mathrm{CH}_{4}$ oxidation pathways.
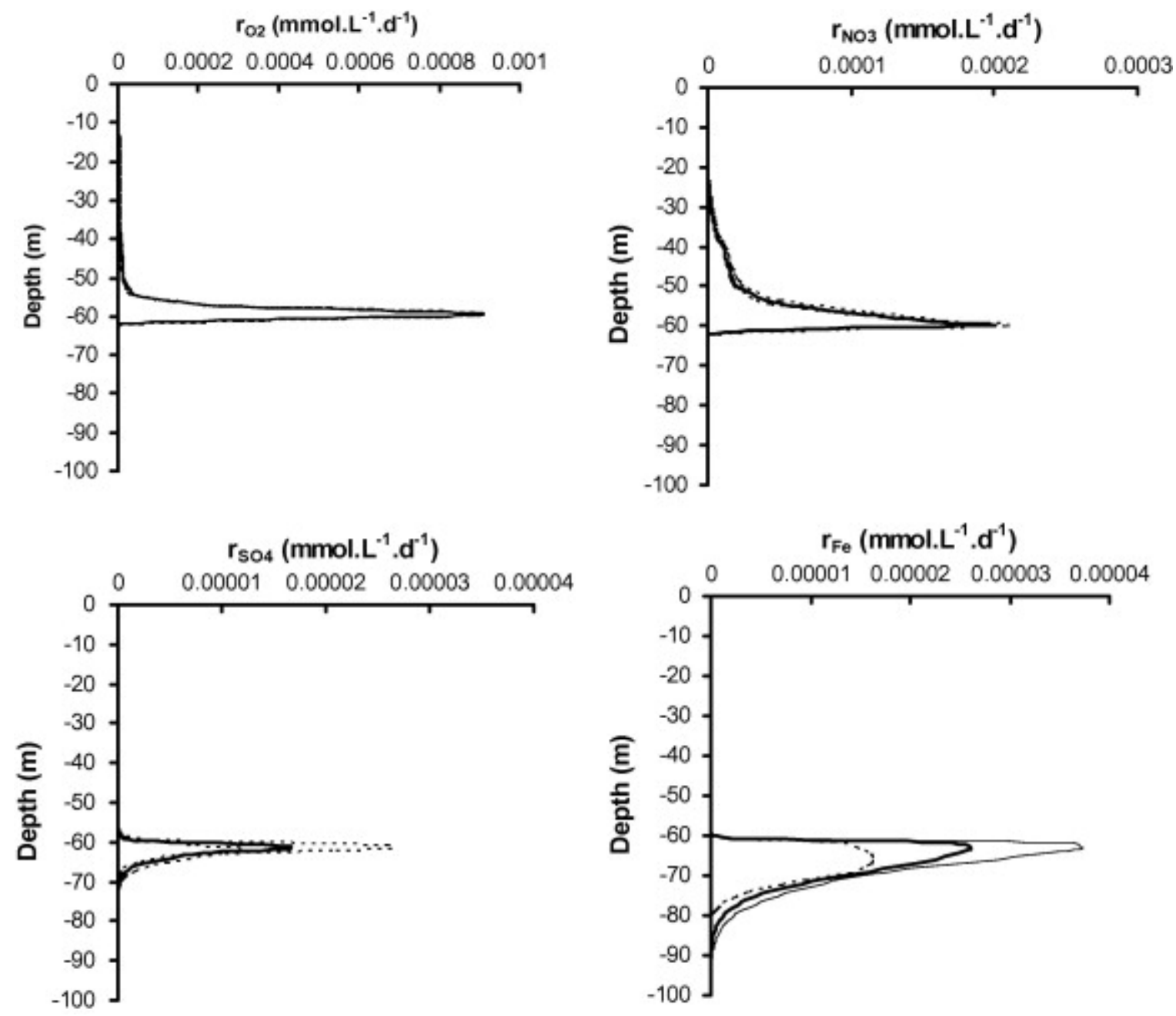

Fig. 12. : Simulated $\mathrm{CH}_{4}$ consumption rates in June 2007 with estimated error bounds. 


\section{Discussion}

\subsection{Aerobic methane oxidation}

According to measurements and model results, both aerobic and anaerobic $\mathrm{CH}_{4}$ oxidation likely occur in the water column of Lake Pavin but are clearly spatially and seasonally dependent. As a result of the interplay of transport and biogeochemical processes, maximum rates of aerobic $\mathrm{CH}_{4}$ oxidation are located at the transition zone between oxic and anoxic conditions, from hypoxia to anoxia (from $50 \mathrm{~m}$ to $62 \mathrm{~m}$ depth).

Maximum rates of aerobic $\mathrm{CH}_{4}$ oxidation calculated by the model at approximately $60 \mathrm{~m}$ depth $\left(1.7 \times 10^{-6} \mathrm{~mol} \mathrm{~L}^{-1}\right.$ day $^{-1}$ and $9.0 \times 10^{-7} \mathrm{~mol} \mathrm{~L}^{-1}$ day ${ }^{-1}$ in February and June respectively), are lower by about a factor of 10 than those expected from the experimentally derived $\mathrm{CH}_{4}$-dependent kinetics $\left(14 \times 10^{-6} \mathrm{~mol} \mathrm{~L}^{-1}\right.$ day $\left.{ }^{-1}\right)$. This is explained by the addition of an $\mathrm{O}_{2}$-dependent term to the kinetic expression implemented in the model and, therefore, by the very low amount of $\mathrm{O}_{2}$ available at this depth.

Finally, calculated values are in very good agreement with results reported previously within the oxycline of stratified lakes by Rudd et al. (1974) $\left(3.8 \times 10^{-6} \mathrm{~mol} \mathrm{~L}^{-1} \mathrm{day}^{-1}\right)$ and by Guérin and Abril (2007) $\left(0.8-200 \times 10^{-6} \mathrm{mmol} \mathrm{L}^{-1} \mathrm{day}^{-1}\right)$. Much lower aerobic rates were also observed in hypersaline lakes such as Mono Lake (Carini et al., 2005) and Big Soda Lake (Iversen et al., 1987), likely due to low methanotrophic activity as a consequence of their high salinity and pH ( [Zehnder and Brock, 1980], [Nauhaus et al., 2002] and Bastviken, 2009).

\subsection{Anaerobic pathways of methane oxidation}

The highest calculated rate of AOM is reported in the vicinity of $60 \mathrm{~m}$ depth $\left(0.2 \times 10^{-6} \mathrm{~mol}\right.$ $\mathrm{L}^{-1}$ day ${ }^{-1}$ ) and is very close to the one measured at this depth. Rates of AOM reported by Iversen et al. (1987) and Joye et al. (1999) in the monimolimnion of Big Soda Lake $\left(\mathrm{CH}_{4}\right.$ concentration of $\left.50 \times 10^{-6} \mathrm{~mol} \mathrm{~L}{ }^{-1}\right)$ and in the bottom layer of Mono Lake $\left(\mathrm{CH}_{4}\right.$ concentration of $\left.8.4 \times 10^{-6} \mathrm{~mol} \mathrm{~L}^{-1}\right)$, respectively, were 2-4-fold lower $\left(48 \times 10^{-9} \mathrm{~mol} \mathrm{~L}^{-1}\right.$ day $^{-1}$ and $48-85$ $\times 10^{-9} \mathrm{~mol} \mathrm{~L}^{-1}$ day $^{-1}$ ). In contrast, an anaerobic $\mathrm{CH}_{4}$ oxidation rate of $3.5 \times 10^{-6} \mathrm{~mol} \mathrm{~L}^{-1}$ day $^{-1}$ was reported in the anoxic waters of the Gulf of Mexico brine pool, characterized by a lower $\mathrm{SO}_{4}^{2-}$ concentration than seawater and $\mathrm{CH}_{4}$ concentrations as high as in Lake Pavin (Wankel et al., 2010).

Beside published anaerobic oxidation of $\mathrm{CH}_{4}$ with $\mathrm{SO}_{4}^{2-}$ as electron acceptor, AOM coupled to $\mathrm{NO}_{3}^{-}$has been recently reported ( [Raghoebarsing et al., 2006], [Islas-Lima et al., 2004] and [Modin et al., 2007] . In the present study, anaerobically mediated $\mathrm{CH}_{4}$ oxidation is mainly coupled to denitrification for the two time periods studied (Fig. 9 and Fig. 11).

AOM with oxides of $\mathrm{Fe}$ and $\mathrm{Mn}$ are presented in the literature as possible pathways of $\mathrm{CH}_{4}$ consumption (Valentine, 2002). These reactions would provide a greater free energy yield than $\mathrm{SO}_{4}^{2-}$-dependent $\mathrm{CH}_{4}$ oxidation. Stimulation of potential anaerobic $\mathrm{CH}_{4}$ oxidation by $\mathrm{Mn}$ oxides in anoxic sediments from Lake Mendota has been reported previously (Zehnder and Brock, 1980). Miura et al. (1992) suggested that, in subsoils, $\mathrm{CH}_{4}$ contributed to a significant proportion of $\mathrm{Fe}(\mathrm{III})$ reduction. Kumaraswamy et al. (2001) have shown a stimulation of $\mathrm{CH}_{4}$ oxidation under anaerobic conditions when Fe(III) was added to anoxic rice soil samples. More recently, Crowe et al. (2010) suggested that anaerobic $\mathrm{CH}_{4}$ oxidation could likely be 
coupled to the reduction of $\mathrm{Fe}$ (and/or $\mathrm{Mn}$ ) (hydr)oxides in the water column of Lake Matano, the world's largest known ferruginous basin. From the latter study, a rate of AOM of $5 \times 10^{-7}$ mol L ${ }^{-1}$ day $^{-1}$ was estimated. It is 10 times higher than the maximum rate estimated for $\mathrm{Fe}$ AOM in this work. The latter is also several times lower than the rates measured within marine sediments by Beal et al. (2009). Finally, although higher concentrations of particulate $\mathrm{Fe}$ are encountered in Lake Pavin compared with those in Lake Matano, denitrification seems to be the preferential $\mathrm{CH}_{4}$ consumption pathway, followed by $\mathrm{Fe}, \mathrm{SO}_{4}^{2-}$ and $\mathrm{Mn}$ reductions in order of decreasing importance.

Many studies have reported AOM in freshwater and/or seawater sediments. By far, the fewest have measured AOM occurring in anoxic water columns and the rates reported are generally lower than rates observed for sediments, primarily because microbial density is substantially higher in sediments. Although, there is no direct evidence for those alternative consumption pathways (Fe/Mn-AOM) in Lake Pavin, the model suggests that Fe-dependent $\mathrm{CH}_{4}$ oxidation may occur in the water column (Fig. 11). These findings are in good agreement with preliminary results of incubations of Lake Pavin water samples from $70 \mathrm{~m}$ depth, with Fe oxides showing that $\mathrm{CH}_{4}$ may be used as electron donor for Fe reduction (Lehours, 2006).

\subsection{Sources and sinks of methane in Lake Pavin}

In February 2007, during the winter mixing period, and to a lesser extent in June 2007, aerobic and anaerobic $\mathrm{CH}_{4}$ oxidation normalized to the whole water column clearly appear as the major sink for $\mathrm{CH}_{4}$ (Table 5). Utsumi et al. (1998) and Guérin and Abril (2007) showed that $\mathrm{CH}_{4}$ oxidation in the water column was the dominant $\mathrm{CH}_{4}$ sink, removing respectively $94 \%$ of $\mathrm{CH}_{4}$ during the overturn period of Lake Nojiri and $90 \%$ of $\mathrm{CH}_{4}$, on average, throughout the year in the Petit Saut reservoir.

The flux of $\mathrm{CH}_{4}$ to the atmosphere estimated in February $2007\left(0.2 \times 10^{-3} \mathrm{~mol} \mathrm{~m}^{-2}\right.$ day $\left.^{-1}\right)$ appears to be lower than the global average flux from lakes: $2.69(1.06-5.6) \times 10^{-3} \mathrm{~mol} \mathrm{~m}^{-2}$ day $^{-1}$; Aselmann and Crutzen, 1989). The Lake Pavin flux is closer to the one of lake 227 reported in Rudd and Hamilton (1978) $\left(0.34 \times 10^{-3} \mathrm{~mol} \mathrm{~m}^{-2} \mathrm{day}^{-1}\right)$ or those found at Big Soda Lake $\left(0.036 \times 10^{-3} \mathrm{~mol} \mathrm{~m}^{-2} \mathrm{day}^{-1}\right.$; Iversen et al., 1987) or at Mono Lake $\left(0.312 \times 10^{-3} \mathrm{~mol}\right.$ $\mathrm{m}^{-2}$ day $^{-1}$; Joye et al., 1999). In June 2007, $\mathrm{CH}_{4}$ flux, although reversed, remains within calculation uncertainties and can be compared to the situation of Lake Baikal where $\mathrm{CH}_{4}$ flux was not significantly different from zero (Schmid et al., 2007). Once normalized to the whole lake surface, air-water exchange is not an important sink or source of $\mathrm{CH}_{4}$ for the two time periods studied (Table 5).

Although methanogenesis occurs in the anoxic water layers, $\mathrm{CH}_{4}$ concentration in Lake Pavin is mainly due to $\mathrm{CH}_{4}$ flux from the sediment. Methane fluxes from sediments calculated from this study are in good agreement with those reported by Iversen et al. (1987) in Big Soda Lake $\left(2.9 \times 10^{-3} \mathrm{~mol} \mathrm{~m}^{-2}\right.$ day $\left.^{-1}\right)$.

Maximum methanogenic rates of $5 \times 10^{-8} \mathrm{~mol} \mathrm{~L}^{-1}$ day $^{-1}$ were calculated at $90 \mathrm{~m}$ depth. Winfrey and Zeikus (1979) and Iversen et al. (1987) also reported water column $\mathrm{CH}_{4}$ production with maximum rates of $1.2 \times 10^{-6} \mathrm{~mol} \mathrm{~L}^{-1} \mathrm{day}^{-1}$ at Knaack Lake and $10.5 \times 10^{-8}$ mol L ${ }^{-1}$ day $^{-1}$ at Big Soda Lake, respectively. According to Winfrey and Zeikus (1979), the existence of a permanent anaerobic habitat enables methanogenic Archae to establish themselves in the anaerobic waters and actively produce $\mathrm{CH}_{4}$. Additionally, the water chemistry in meromictic lakes is also an important factor in determining whether 
methanogenesis occurs in the water column or in the sediment. The absence of $\mathrm{SO}_{4}^{2-}$ and $\mathrm{NO}_{3}^{-}$in the bottom waters of Lake Pavin enables methanogenesis. Calculations demonstrate that $\mathrm{CH}_{4}$ produced in the water column results mainly from the degradation of dissolved organic C. In the model, it is assumed that DOC is highly biodegradable. According to Pourriot and Meybeck (1995) the organic matter resulting from phytoplankton lysis presents a high fraction of biodegradable organic $\mathrm{C}$ (>80\% of DOC).

Interestingly, in the upper layers of the mixolimnion (from the surface to approximately 12 $\mathrm{m}$ ), significantly higher $\mathrm{CH}_{4}$ concentrations were measured in June and September 2006 than those from lower layers (from $12 \mathrm{~m}$ to $55 \mathrm{~m}$ ), suggesting $\mathrm{CH}_{4}$ generation in the photic zone (Fig. 4b). Liu et al. (1996) also reported higher $\mathrm{CH}_{4}$ concentrations in surface water of the highly productive Lake Lugano. These $\mathrm{CH}_{4}$ maxima in the oxic surface layers of lakes may correspond to the presence of anaerobic microhabitats in particulate organic matter (Karl and Tilbrook, 1994), and/or aerobic $\mathrm{CH}_{4}$ production through alternative pathways, analog to methylphosphonate decomposition recently evidenced in the ocean (Karl et al., 2008).

An alternative explanation for the higher $\mathrm{CH}_{4}$ content in surface layers than in the middle layers is proposed by Bastviken et al. (2008): the enrichment may be due to $\mathrm{CH}_{4}$ diffusion from epilimnetic sediment combined with higher water turbulence in the surface layer.

In June 2007, $\mathrm{CH}_{4}$ sinks counterbalance sources and participate in maintaining the observed steady state in Lake Pavin (Table 5). In February 2007, the magnitude of the sinks is about twice as large as the sources. However, when compared to the whole stock of $\mathrm{CH}_{4}$, seasonal variations in $\mathrm{CH}_{4}$ sinks are clearly smoothed on the yearly scale. One can also calculate an average biogeochemical renewal time (stock/sinks) ranging from 12 to 30 years for $\mathrm{CH}_{4}$. The stock of $\mathrm{CH}_{4}$, is essentially located in the monimolimnion which has a water residence time of 70 years (Assayag et al., 2008). This stresses the importance of biogeochemical processes as main drivers of $\mathrm{CH}_{4}$ control in Lake Pavin.

\section{Conclusions}

A biogeochemical model was developed and applied to data from Lake Pavin in order to assess the most significant pathways of $\mathrm{CH}_{4}$ consumption in this lake. For instance, aerobic and anaerobic oxidations of $\mathrm{CH}_{4}$ both occur in the water column of Lake Pavin, with aerobic oxidation being the dominant pathway. The highest rate of anaerobic oxidation of $\mathrm{CH}_{4}$ is observed at approximately $60 \mathrm{~m}$ depth where $\mathrm{NO}_{3}^{-}$is the main electron acceptor involved. Iron dependent anaerobic $\mathrm{CH}_{4}$ oxidation may occur in the water column but remains a minor pathway. Methane oxidation rates seem to be sensitive to vertical mixing and to the combination of all the kinetic parameters of the $\mathrm{CH}_{4}$ consumption pathways. The main source of $\mathrm{CH}_{4}$ is always associated with the benthic flux with little water column methanogenesis, while $\mathrm{CH}_{4}$ sinks are more variable. Methane oxidation is the main sink and $\mathrm{CH}_{4}$ evasion through water-atmosphere exchange corresponds to less than $10 \%$ of the biogeochemical sinks. This detailed study also shows that interpretation of $\mathrm{CH}_{4}$ monitoring in Lake Pavin has to consider the interannual and decadal time scales.

\section{Acknowledgments}


The University Blaise Pascal of Clermont-Ferrand allowed the utilization of Besse biological station nearby the lake and provided boats and a platform. This work was a part of the METANOX project, funded by the ANR-EC2CO.

\section{References}

Abril and Iversen, 2002 G. Abril and N. Iversen, Methane dynamics in a shallow, non-tidal, estuary (Randers Fjord, Denmark). Mar. Ecol. Prog. Ser., 230 (2002), pp. 171-181.

Aeschbag-Hertig et al., 2002 W. Aeschbag-Hertig, M. Hofer, M. Schmid, R. Kipfer and D.M. Imboden, The physical structure and dynamics of a deep, meromictic crater lake (Lac Pavin, France). Hydrobiologia, 487 (2002), pp. 111-136.

Alain et al., 2006 K. Alain, T. Holler, F. Musat, M. Elvert, T. Treude and M. Kruger, Microbiological investigation of methane- and hydrocarbon discharging mud volcanoes in the Carpathian Mountains, Romania. Environ. Microbiol., 8 (2006), pp. 574-590.

Albéric et al., 2000 P. Albéric, E. Viollier, D. Jézéquel, C. Grosbois and G. Michard, Interactions between trace elements and dissolved organic matter in the stagnant anoxic deep layer of a meromictic lake. Limnol. Oceanogr., 45 (2000), pp. 1088-1096.

Aselmann and Crutzen, 1989 I. Aselmann and P. Crutzen, Global distribution of natural freshwater wetlands and rice paddies, their net primary productivity, seasonality and possible methane emissions. J. Atmos. Chem., 8 (1989), pp. 307-358.

Assayag et al., 2008 N. Assayag, D. Jézéquel, M. Ader, E. Viollier, G. Michard, F. Prévot and P. Agrinier, Hydrological budget, carbon sources and biogeochemical processes in Lac Pavin (France): constraints from d180 of water and d13C of dissolved inorganic carbon. Appl. Geochem., 23 (2008), pp. 2800-2816.

Bastviken, 2009 Bastviken, D., 2009. Methane. In: Likens, G.E. (Ed.), Encyclopedia of Inland Waters, vol. 2. Elsevier, Oxford, pp. 783-805..

Bastviken et al., 2008 D. Bastviken, J.J. Cole, M.L. Pace and M.C. Van de Bogert, Fates of methane from different lake habitats: Connecting whole-lake budgets and $\mathrm{CH}_{4}$ emissions,.$J$. Geophys. Res., 113 G02024 (2008), pp. 1-13 doi:10.1029/2007JG000608.

Beal et al., 2009 E. Beal, C.H. House and V.J. Orphan, Manganese- and iron-dependent marine methane oxidation. Science, 325 (2009), pp. 184-187.

Boudreau, 1997 B. Boudreau, Diagenetic Models and Their Implementation, Springer-Verlag, Berlin (1997).

Carini et al., 2005 S. Carini, B. Nasreen, G. LeCleir and S. Joye, Aerobic methane oxidation and metanotroph community composition during seasonal stratification in Mono Lake, California (USA). Environ. Microbiol., 7 (2005), pp. 1127-1138.

Carrias, 1996 Carrias, J-F., 1996. La boucle microbienne en milieu lacustre : structure et fonctionnement des communautés picoplanctoniques et des protistes flagellés et ciliés. $\mathrm{PhD}$ Thesis. Univ. Blaise Pascal, Clermont-Ferrand, France.. 
Carrias et al., 1998 J-F. Carrias, C. Amblard and G. Bourdier, Seasonal dynamics and vertical distribution of planktonic ciliates and their relationship to microbial food resources in the oligomesotrophic Lake Pavin. Arch. Hydrobiol., 143 (1998), pp. 227-255.

Colombet et al., 2006 J. Colombet, T. Sime-Ngando, H.M. Cauchie, G. Fonty, L. Hoffmann and G. Demeure, Depth-related gradients of viral activity in Lake Pavin. Appl. Environ. Microbiol., 72 (2006), pp. 4440-4445.

Conrad et al., 1999 M.E. Conrad, A.S. Templeton, P.F. Daley and L. Alvarez-Cohen, Seasonally-induced fluctuations in microbial production and consumption of methane during bioremediation of aged subsurface refinery contamination. Environ. Sci. Technol., 33 (1999), pp. 4061-4068.

Crowe et al., 2010 Crowe, S.A., Katsev, S., Leslie, K., Sturm, A., Magen, C., Nomosatryo, S., Pack, M.A., Kessler, J.D., Reeburgh, W.S., Roberts, J.A., Gonzalez, L., Douglas Haffner, G., Mucci, A., Sundby, B., Fowle, D., 2010. The methane clycle in ferruginous Lake Matano. Geobiology 1-18. doi:10.1111/j.1472-4669.2010.00257.x..

Cytryn et al., 2000 E. Cytryn, D. Minz, R.S. Oremland and Y. Cohen, Distribution and diversity of Archaea corresponding to the limnological cycle of a hypersaline stratified lake (Solar Lake, Sinai, Egypt). Appl. Environ. Microbiol., 66 (2000), pp. 3269-3276.

Devaux et al., 1983 Devaux, J., Lair, N., Amblard, 1983. Un écosystème lacustre profond: le lac Pavin. In: Problèmes d'Ecologie. Ecosystèmes Limniques. Bourlière, F., Masson, France, 2005. doi:10.1029/2005JG000010..

Eller et al., 2005 G. Eller, L.K. Kanel and M. Kruger, Cooccurrence of aerobic and anaerobic methane oxidation in the water column of lake Plusssee. Appl. Environ.

Microbiol., 71 (2005), pp. 8925-8928.

Elvert et al., 2000 M. Elvert, E. Suess, J. Greinert and M.J. Whiticar, Archaea mediating anaerobic methane oxidation in deep-sea sediments at cold seeps of the eastern Aleutian subduction zone. Org. Geochem., 31 (2000), pp. 1175-1187.

Ertefai et al., 2008 T.F. Ertefai, Meredith, M.C. Fisher, H.F. Fredricks, J.S. Lipp, A. Pearson, B. Daniel, K.M. Udert, C.M. Cavanaugh, Gschwend, M. Philip and K-U. Hinrichs, Vertical distribution of microbial lipids and functional genes in chemically distinct layers of a highly polluted meromictic lake. Org. Geochem., 39 (2008), pp. 1572-1588.

Guérin and Abril, 2007 F. Guérin and G. Abril, Significance of pelagic aerobic methane oxidation in the methane and carbon budgets of a tropical reservoir, . J, Geophys. Res. Biogeosci., (2007), p. 112 doi:10.1029/2006JG000393.

Hunter et al., 1998 K.S. Hunter, Y. Wang and P. Van Cappellen, Kinetic modelling of microbially-driven redox chemistry of subsurface environments: coupling transport, microbial metabolism and geochemistry. J. Hydrol., 209 (1998), pp. 53-80.

Islas-Lima et al., 2004 S. Islas-Lima, F. Thalasso and J. Gomez-Hernandez, Evidence of anoxic methane oxidation coupled to denitrification. Water Res., 38 (2004), pp. 13-16. 
Iversen et al., 1987 N. Iversen, R.S. Oremland and M.J. Klug, Big Soda Lake (Nevada). 3. Pelagic methanogenesis and anaerobic methane oxidation. Limnol. Oceanogr., 32 (1987), pp. 804-814.

Joye et al., 1999 S.B. Joye, T.L. Connell, G. Miller, R.S. Oremland and R.S. Jellison, Oxidation of ammonia and methane in an alkaline, saline lake. Limnol.

Oceanogr., 44 (1999), pp. 178-188.

Karl and Tilbrook, 1994 D.M. Karl and B.D. Tilbrook, Production and transport of methane in oceanic particulate organic matter. Nature, 368 (1994), pp. 732-734.

Karl et al., 2008 D.M. Karl, L. Beversdorf, K.M. Björkman, M.J. Church, A. Martinez and E.F. DeLong, Aerobic production of methane in the sea. Nature Geosci., 1 (2008), pp. 473478.

Kumaraswamy et al., 2001 S. Kumaraswamy, B. Ramakrishnan and N. Sethunathan, Methane production and oxidation in an anoxic rice soil as influenced by inorganic redox species. Wetlands and Aquatic Processes. J. Environ. Qual., 30 (2001), pp. 2195-2201.

Lehours, 2006 Lehours, A.-C., 2006. La communauté procaryotique dans les zones anoxiques des deux écosystèmes lacustres : structure et diversité. Étude plus particulière de son écologie dans le monimolimnion d'un lac méromictique (Lac Pavin). Ph.D. Thesis. Laboratoire de Biologie des protistes, UMR 6023, CNRS-Clermont-Ferrand..

Lehours et al., 2005 A.-C. Lehours, C. Bardot, A. Thenot, D. Debroas and G. Fonty, Anaerobic microbial communities in Lake Pavin, a unique meromictic lake in France. Appl. Environ. Microbiol., 71 (2005), pp. 7389-7400.

Lehours et al., 2007 A.-C. Lehours, P. Evans, C. Bardot, K. Joblin and G. Fonty, Phylogenetic diversity of archae and bacteria in the anoxic zone of a meromictic lake (Lake Pavin, France). Appl. Environ. Microbiol., 73 (2007), pp. 2016-2019.

Lemarchand et al., 2006 C. Lemarchand, L. Jardillier, J.F. Carrias, M. Richardot, D. Debroas, T. Sime-Ngando and C. Amblard, Community composition and activity of prokaryotes associated to detrital particles in two contrasting lake ecosystems. FEMS Microbiol. Ecol., 57 (2006), pp. 442-451.

Lidstrom and Somers, 1984 M.E. Lidstrom and L. Somers, Seasonal study of methane oxidation in lake Washington. Appl. Environ. Microbiol., 47 (1984), pp. 1255-1260.

Liss and Merllivat, 1986 Liss, P.S., Merlivat, L., 1986. Air sea gas exchange rates: introduction and synthesis. In: Buat Ménard, P. (Ed.), The Role of Air-Sea Exchange in Geochemical Cycling. Nato ASI Series, pp. 113-127..

Liu et al., 1996 R. Liu, A. Hofmann, O. Gullaçar, P-Y. Faverger and J. Dominik, Methane concentration profiles in a lake with a permanently anoxic hypolimnion (lake Lugano, Switzerland-Italy). Chem. Geol., 133 (1996), pp. 201-209. 
Lovley and Phillips, 1987 D.R. Lovley and E.J.P. Phillips, A rapid assay for microbially reducible ferric iron in aquatic sediments. Appl. Environ. Microbiol., 53 (1987), pp. 15361540 .

Michard, 1989 Michard G., 1989. Equilibres chimiques dans les eaux naturelles, Publisud ed..

Michard et al., 1994 G. Michard, E. Viollier, D. Jézéquel and G. Sarazin, Geochemical study of a crater lake: the Lake Pavin, France - identification, location and quantification of chemical reactions in the lake. Chem. Geol., 115 (1994), pp. 103-115.

Michard et al., 2003 G. Michard, D. Jezequel and E. Viollier, Vitesses de réaction de dissolution et précipitation au voisinage de l'interface oxydo-réducteur dans un lac méromictique : le lac Pavin (Puy de Dôme, France). Rev. Sci. Eau, 16 (2003), pp. 199-218. |

Miura et al., 1992 Y. Miura, A. Watanabe, J. Murase and M. Kimura, Methane production and its fate in paddy fields: II. Oxidation of methane and its coupled ferric oxide reduction in subsoil. Soil Sci. Plant Nutr., 38 (1992), pp. 673-679.

Modin et al., 2007 O. Modin, K. Fukushi and Yamamoto, Denitrification with methane as external carbon source. Water Res., 41 (2007), pp. 2726-2738.

Nauhaus et al., 2002 K. Nauhaus, A. Boetius, M. Kruger and Widdel, In vitro demonstration of anaerobic oxidation of methane coupled to sulphate reduction in sediment from a marine gas hydrate area. Environ. Microbiol., 4 (2002), pp. 296-305.

Omlin et al., 2001 M. Omlin, P. Reichert and R. Forster, Biogeochemical model of lake Zurich: model equations and results. Ecol. Model., 141 (2001), pp. 77-103.

Pourriot and Meybeck, 1995 R. Pourriot and M. Meybeck, Limnologie Générale, Masson, Paris (1995).

Quiblier-Lloberas et al., 1996 C. Quiblier-Lloberas, G. Bourdier, C. Amblard and D. Pépin, Impact of grazing on phytoplankton in Lake Pavin (France): contribution of different zooplankton groups. J. Plankton Res., 18 (1996), pp. 305-322.

Raghoebarsing et al., 2006 A.A. Raghoebarsing, A. Pol, K.T. Van de Pas-Schoonen, A.J.P. Smolders, K.F. Ettwig, I.C. Ripstra, S. Schouten, J.S.S. Damsté, H.J.M. Op den Camp, M.S.M. Jetten and M. Strous, A microbial consortium couples anaerobic methane oxidation to denitrification. Nature Lett., 440 (2006), pp. 918-921.

Regnier et al., 2006 P. Regnier, A.W. Dale, C. Pallud, Y. van Lith, S. Bonneville, C. Hyacinthe, M. Thullner, A.M. Laverman and P. Van Cappellen, Incorporating geomicrobial processes in reactive transport models of subsurface environments, G. Nutzmann, P. Viotti, P. Aagaard, Editors , Reactive Transport in Soil and Groundwater, Springer (2006) pp. 109125.

Reichert, 1998 Reichert, P., 1998. AQUASIM 2.0 Computer Program for the Identification and Simulation of Aquatic Systems. User Manuel. EAWAG Report. ISBN 3-906484-19-5.. 
Reichert et al., 2001 P. Reichert, D. Borchardt, M. Henze, W. Rauch, P. Shanahan, L. Somlyody and P. Vanrolleghem, River water quality no. 1 (RWQM1): II. Biochemical process equations. Water Sci. Technol., 43 (2001), pp. 11-30.|

Robie et al., 1978 R.A. Robie, B.S. Hemingway and J.R. Fisher, Thermodynamic properties of mineral and related substances at $298.15 \mathrm{~K}$ and 1 bar pressure and higher temperature. US Geol. Surv. Bull., (1978), pp. 1452-1456.

Rudd and Hamilton, 1978 J.W.M. Rudd and R.D. Hamilton, Methane cycling in a eutrophic shield lake and its effects on the whole lake metabolism. Limnol. Oceanogr., 23 (1978), pp. 337-348.

Rudd et al., 1974 J.W.M. Rudd, R.D. Hamilton and N.E.R. Campbell, Measurement of microbial oxidation of methane in lake water. Limnol. Oceanogr., 19 (1974), pp. 519-524. |

Sanders, 1999 Sanders, R., 1999. Compilation of Henry's Law Constants for Inorganic and Organic Species of Potential Importance in Environmental Chemistry. <http://www.mpchmainz.mpg.de/rsander/res/henry.html>..

Schmid et al., 2007 M. Schmid, M. De Batist, N.G. Granin, V.A. Kapitanov, D.F. McGinnis, I.B. Mizandrontsev, A.I. Obzhirov and A. Wuest, Sources and sinks of methane in lake Baikal: a synthesis of measurements and modelling. Limnol. Oceanogr., 52 (2007), pp. 1824-1837.

Sigg, 1985 L. Sigg, Metal transfer mechanisms in lakes; the role of settling particles, W. Stumm, Editor, Chemical Processes in Lakes, Wiley and Sons, New York (1985) pp. 283309.

Smith et al., 1991 R.L. Smith, B.L. Howes and S.P. Garabesian, In situ measurement of methane oxidation in groundwater by using natural-gradient tracer test. Appl. Environ. Microbiol., 57 (1991), pp. 1997-2004.

Smith and Jaffé, 1998 S.L. Smith and P. Jaffé, Modeling the transport and reaction of trace metals in water-saturated soils and sediments. Water Resour. Res., 34 (1998), pp. 31353147.

Solomon et al., 2007 Solomon, S., Qin, D., Manning, M., Alley, R.B., Berntsen, T., Bindoff, N.L., Chen, Z., Chidthaisong, A., Gregory, J.M., Hegerl, G.C., Heimann, M., Hewitson, B., Hoskins, B.J., Joos, F., Jouzel, J., Kattsov, V., Lohmann, U., Matsuno, T., Molina, M., Nicholls, N., Overpeck, J., Raga, G., Ramaswamy, V., Ren, J., Rusticucci, M., Somerville, R., Stocker, T.F., Whetton, P., Wood, R.A., Wratt, D., 2007. Contribution of working group I to the fourth assessment report of the intergovernmental panel on climate change. Technical summary. In: Solomon, S., Qin, D., Manning, M., Chen, Z., Marquis, M., Averyt, K.B., Tignor, M., Miller, H.L. (Eds.), Climate Change 2007: The Physical Science Basis. Cambridge University Press, Cambridge, UK and New York, USA..

Taillefert and Gaillard, 2002 M. Taillefert and J-F. Gaillard, Reactive transport modelling of trace elements in the water column of a stratified lake: iron cycling and metal scanvenging. $J$. Hydrol., 256 (2002), pp. 16-34. 
Thiam et al., in preparation Thiam, A., Viollier, E., Jézéquel, D., Groleau, A., Prévot, F., Lopes, F., Lazar, H., Pèpe, M., Lafortune, S., Albéric, P., Quiblier, C., Bura-Nakić, E., Ciglenecki-Jusic., I., in preparation. Biogeochemical dynamics of molybdenum in a crater lake: seasonal impact and long term removal..

Utsumi et al., 1998 M. Utsumi, Y. Nojiri, T. Nakamura, T. Nozawa, A. Otsuki and H. Seki, Dynamics of dissolved methane and methane oxidation in dimictic lake Nojiri during winter. Limnol. Oceanogr., 43 (1998), pp. 471-480.

Valentine, 2002 D.L. Valentine, Biogeochemistry and microbial ecology of methane oxidation in anoxic environments: a review. Antonie van Leeuwenhoek, 81 (2002), pp. 271282.

Van Cappellen and Wang, 1996 P. Van Cappellen and Y. Wang, Cycling of iron and manganese in surface sediments: a general theory for the coupled transport and reaction of carbon, oxygen, nitrogen, sulfur, iron and manganese. Am. J. Sci., 296 (1996), pp. 197-243.

Van Cappellen et al., 1993 Van Cappellen, P., Gaillard, J-F, Rabouille, C. 1993.

Biogeochemical transformations in sediments: kinetic models of early diagenesis. In: Wollast, R., Mackenzie, F.T., Chou, L. (Eds.), Interactions of C, N, P and Biogeochemical Cycles and Global Change, vol. 14. NATO ASI Series, pp. 401-445..

van Huissteden et al., 2005 J. van Huissteden, T.C. Maximov and A.J. Dolman, High $\mathrm{CH}_{4}$ flux from an arctic floodplain (Indigirka lowlands, Eastern Siberia). J. Geophys.

Res., 110 (2005), p. G02002.

van Huissteden et al., 2008 J. van Huissteden, T.C. Maximov, A.V. Kononov and A.J. Dolman, Summer soil $\mathrm{CH}_{4}$ emission and uptake in taiga forest near Yakutsk, Eastern Siberia. Agric. Forest Meteorol., 148 (2008), pp. 2006-2012.

Viollier, 1995 Viollier, E., 1995. Géochimie des éléments traces en milieu lacustre. Ph.D Thesis. Univ. Paris $7 .$.

Viollier et al., 1995 E. Viollier, P. Alberic, D. Jézéquel, G. Michard, M. Pèpe and G. Sarazin, Geochemical study of a crater lake: the Lake Pavin, France - trace element behaviour in the monimolimnion. Chem. Geol., 125 (1995), pp. 161-172.

Viollier et al., 1997 E. Viollier, G. Michard, D. Jézéquel, M. Pèpe and G. Sarazin, Geochemical study of a crater lake: Lake Pavin, Puy de Dome, France. Constraints afforded by the particulate matter distribution in the element cycling within the lake. Chem.

Geol., 142 (1997), pp. 225-241.

Wankel et al., 2010 S.D. Wankel, S.B. Joye, V.A. Samarkin, S.R. Shah, G. Friederich, J. Melas-Kyriazi and P.R. Girguis, New constrants on methane fluxes and rates of anaerobic methane oxidation in a Gulf of Mexico brine pool via in situ mass spectrometry. Deep Sea Res. II., 57 (2010), pp. 2022-2029.

Whiticar, 1993 Whiticar, M.J., 1993. Stable isotopes and global budgets. In: Khalil, M.A.K. (Ed.), Atmospheric Methane: Sources, Sinks, and Role in Global Change. NATO ASI Series I, Global Environmental, pp. 138-167 (Change 13, Chapter 8).. 
Winfrey and Zeikus, 1979 M.R. Winfrey and J.G. Zeikus, Microbial methanogenesis and acetate metabolism in a meromictic lake. Appl. Environ. Microbiol., 37 (1979), pp. 213-221.

Zehnder and Brock, 1980 A.J.B. Zehnder and T.D. Brock, Anaerobic methane oxidation: occurrence and ecology. Appl. Environ. Microbiol., 39 (1980), pp. 194-204. 